\title{
Informal Bargaining Process: An Analysis of the SEC's Regulation of the New York Stock Exchange
}

Government would keep the shotgun, so to speak, behind the door, loaded, well oiled, cleaned, ready for use but with the hope it would never have to be used. ${ }^{1}$

A primary responsibility of the Securities and Exchange Commission is to oversee operation of the nation's securities exchanges "for the protection of investors, ... to insure fair dealing in securities ... [and] to insure fair administration." 2 The Securities and Exchange Act of 1934 established a new regulatory agency, equipped with the surveillance, rulemaking and enforcement tools of the administrative process, to accomplish these goals. ${ }^{3}$ Despite recent serious problems in the securities industry, ${ }^{4}$ the SEC has not been subjected to blistering attacks as have other regulatory agencies; but the SEC's reputation should not obscure faults in the procedure which has evolved for oversight of securities exchanges. The Exchange Act outlines an administrative pattern $^{6}$ to which the traditional concerns of administrative law-rulemaking, fair hearing procedures, articulation of policy, circumscribed discretion and judicial review-are relevant as a means of controlling the agency. ${ }^{7}$ The traditional pattern, however, does not correspond with the SEC's actual regulation of securities exchanges.

This Note describes the primarily informal, customarily secret, highly discretionary regulatory pattern which in reality defines the SEC's relationship with the New York Stock Exchange. ${ }^{8}$ A close working re-

1. W. Douglas, Democracy and Finance 82 (1940).

2. Securities and Exchange Act of 1934 \$ 19(b), 15 U.S.C. $\$ 785$ (1964).

3. Great faith in rational planning by experts in administrative agencies vas evident in the early New Deal era, as outlined in Fick, Issues and Accomplishments in Administrative Regulation: Some Political Issues, 26 LAw \& CoNTEMP. ProB. 283, 289.91 (1961). Faith in the regulatory process was explicit in relation to the SEC in statements of President Franklin Roosevelt and the SEC's first chairman Joseph Kennedy, as quoted in R. DEBErrs, The New Deal's SEC: The Formative Years 30-31, 97 (1964).

4. The most dramatic problems have involved bankruptcies of several major investment houses. N.Y. Times, March 23, 1970, at 59, col. 7.

5. See, e.g., J. TURNER, THE CHEMICAL FEAST (1970) on the Food and Drug Administration; R. FELLAIETh, THE INTERSTATE COMMIERCE OMIISIION (1970) on the I.C.C.; and AMERICAN BAR Association, REPORT of the CoMmission to Study the FederAl Trade COMIMISSION (1969).

6. See pp. 813-15 infra.

7. See pp. 812-13 infra.

8. The Note concentrates exclusively on regulation of one security exchange, the Nen: York Stock Exchange. The Big Board transacts more than 70 per cent of the dollar value of all stock transactions on United States exchanges. NEW YORE STOCK Excrusce, FAcT 
lationship, marked by frequent informal contact, has developed between SEC officials and the Exchange. Most decisions are hammered out in closed-door bargaining sessions where vast discretion rests with the agency. ${ }^{9}$ Recent commentaries $^{10}$ and judicial decisions ${ }^{11}$ have focused on the general deficiencies of informal regulatory practices. This Note describes a particular informal regulatory process as it has operated over the past ten years. It seeks to evaluate the advantages and disadvantages of more formal structuring of that process through announcement of issues under consideration, public hearings on major issues and articulation of policy.

\section{The Informal Bargaining Process}

\section{A. Structuring Regulatory Discretion}

Administrative agencies are delegated authority by the legislature. Discretion must accompany the authority because the purpose of the agency is to perform regulation and oversight which the legislature feels incapable of accomplishing through more explicit legislation. ${ }^{12}$ Statutory authorization for an agency gives some guidance to the agency, although it may be minimal, in structuring discretion procedurally and pursuing legislative goals substantively. Professor Kenneth C. Davis suggests seven instruments for the "structuring of

Book (1970). It has been the pace-setter in organization of operations, setting of commis. sion rates and establishment of self-regulatory rules. The Exchange's rules are important not only because they have been copied, but because many New York members are also members of other exchanges and the Big Board claims responsibility for member conduct in any line of business. SEC, Special Study of Securities Markets pt. 2, at 706, pt. 4, at 504 (1963) [hereinafter cited as Special Study].

9. A number of SEC officials, private practitioners, securities industry members and journalists were interviewed in connection with this Note. As all the interviews werc understood to be for background only, it is impossible to cite statements from thosc interviewed as documentation of specific findings. However, all of those intervicwed cont. firmed the general description here that the SEC and Exchange have a close working relationship characterized by informal bargaining on regulatory issues. Unfortunately, negotiators for the New York Stock Exchange refused to speak with the author of this Note.

10. See, e.g., K. Davis, Discretionary Justice: A Prelininary INQuiky (1969).

11. To prevent the public from being "fenced out of its role in rate-making," the D.C. Circuit last summer ordered the Civil Aeronautics Board to hold public hearings on airline fares. Moss v. CAB, 430 F.2d 891, 900 (D.C. Cir. 1970). SEC informal regulation of the exchanges will be scrutinized as the result of the remand in Thill Securities Corp. v. New York Stock Exchange, 433 F.2d 264 (7th Cir. 1970). The Circuit Court reversed the lower court's finding of an implied antitrust exemption for Exchange price fixing and remanded because it found "no evidence in the record that the SEC is exercising actual and adequate review jurisdiction." Thill, supra at 271 . The trial court has thus becn asked to survey the appropriateness of the informal bargaining process at the SEC. Judicial review of informal regulatory processes is discussed further at pp. 839-812 infra.

12. See, e.g., L. Jaffe, Judicial Control of Administrative Agrion 33.41 (1965). 
discretionary power" by administrative agencies: "open plans, open policy statements, open rules, open findings, open reasons, open precedents" and fair non-judicial procedure. ${ }^{13}$ Open plans, policy statements and rules "close the gap between what the agency' and its staff know about the agency's law and policy and what an outsider can know."14 They force an agency to articulate clearly its decisions, both long and short range, and expose them to public scrutiny. Open findings and reasons force an agency to base decisions on a public record, preventing careless, uninformed or hasty decisions and leading to candid correlation of findings to agency plans, policies and rules. ${ }^{15}$ Open precedents force the agency to strive for consistency, preventing the injustice of random policies. ${ }^{10}$ Fair non-judicial procedures operate against arbitrary use of discretion by allowing affected parties to know what is being considered and to respond before a decision is made. Fair procedures include keeping all views expressed to the agency open for public inspection and allowing all interested parties to have the opportunity to express views. ${ }^{17}$ "Informal regulation," as discussed here, makes minimal use of these seven instruments. By contrast increased use of the seven instruments will throughout this Note be considered "formalization" of the regulatory pattern. ${ }^{18}$

\section{B. The SEG's Statutory Framework}

Explicit in the Exchange Act is a two-level regulatory pattern. The agency regulates securities markets directly in some areas of their

13. K. Davis, supra note 10 , at 98 . Davis' criteria emphasize openness: "Openness is the natural enemy of arbitrariness and a natural ally in the fight against injustice."

14. Id. at 102.

15. Id. at 103-06. Davis emphasizes that, although findings are traditionally thought of as the result only of hearings and court proceedings, their value is equally important in more informal information gathering.

16. Although precedents cannot be binding in a judicial sense if flexible regulation is to be possible, they should still set some guidelines for agency action. Davis categorizes their use with the spectrum: "precedents are (1) almost always binding, (2) always considered and usually binding. (3) usually considered but seldom binding, (4) occasionally considered but never binding, and (5) almost never considered." Id. at 106.

17. Id. at 116-20.

18. Use of "formal" in the administrative context raises for many the forcboding specter of judicial-type, highly structured hearings, with judges shielded from ex parle contact with the parties; but to use the word thus is a mistalie. There is a spectruin of decision-making processes, completely unstructured with almost no formality at one end and very structured with much formality at the other. Discussion of formalizing SEC procedures here is meant to refer to shifts on that spectrum toward more structuring. without suggesting shifts be made all the way to judicialized proceedings. The purpose of examining weaknesses in informal procedures is not to discover how "to maximize the use of the seven methods of structuring but to locate the optimum degree of structuring in each respect for each discretionary power." K. Davis, supra note 10, at 99 (emphasis in original deleted). 
activity; it also oversees exchange self-regulation. ${ }^{10}$ Congress felt in 1934 that it would be impractical for a government body to perform the sensitive, day-to-day, detailed supervision of the fast-moving securities industry, and that there existed in this industry unethical, as well as illegal, activities which could best be curbed through self-regulation. ${ }^{20}$ But, because self-regulators have a natural tendency to protect and favor their own interests, often to the detriment of the public,a1 Congress placed on the SEC the obligation of overseeing self-regulation. ${ }^{22}$ As chairman of the SEC in the late 1930's, Justice Douglas described the two-level regulatory pattern with his gun-behind-the-door metaphor. Describing the process as "something more than cooperation," Douglas hoped that it "would be unnecessary for the Government to interfere" with self-regulation; but emphasized that hopes did not relieve the SEC from doing "the job which is ours under the law."

The SEC's "job under the law" is of three major types:

(1) Under Section 6, the exchanges are required to file registration statements with data on their "organization, rules of procedure, and membership ... and 'rules of the exchange.' "24 Before granting registration, the SEC must find exchange rules "just and adequate to insture fair dealing and to protect investors." ${ }^{25}$ If an exchange has violated the securities laws, or has failed to enforce member compliance with the SEC's or its rules, the Commission can under Section 19(a) expel or suspend an exchange officer or suspend or withdraw an exchange's registration. ${ }^{26}$

(2) The SEC has direct authority under Sections 10 and 11 as it deems "necessary or appropriate in the public interest or for the protection of investors" to prescribe rules for exchange specialists, odd lot dealers and

19. See pp. 814-815 infra.

20. The rationale for self-regulation was explained by John Dickinson, chairman of the Roper Committee which drafted the Exchange Act, at Hearings on H.R. 7852 and H.R. 8720 Before the House Comm. on Interstate and Foreign Commerce, 73d Congy." "dd Sess. 513-15 (1934) [hereinafter cited as Exchange Act Hearings]. A similar rationalc for self-regulation was expressed more recently by a former SEC chairman, W. CARY, YoLIrics AND THE REGULATORX AGENCIES 43-44 (1967).

21. Dickinson testimony, Exchange Act Hearings, sutpra note 20, at 514. There remains a need for oversight of profit-secking self-regulators. See Cary, Self-Regulation in the Securities Industry, 49 A.B.A.J. 244 (1963).

22. See p. 815 infra.

23. W. Douclas, supra note 1 , at 82.83 . The second SEC chairman, James Landis, expressed similar sentiments: "The SEC has to be both crackdown and cooperating agency, depending on the circumstances," quoted in R. DEBEDTs, supra note 3 , at 110.

24. Securities and Exchange Act of $1934 \S \S 6(\mathrm{a})(2)$ and $6(\mathrm{a})(3), 15$ U.S.C. $\S \S 78 \mathrm{f}(\mathrm{a})(2)$ and 78(a)(3) (1964).

25. Securities and Exchange Act of 1934 \& 6(d), 15 U.S.C. $\S 78 f(d)$ (1961).

26. Securities and Exchange Act of $1934 \$ \$ 19(a)(1)$ and $19(a)(3), 15$ U.S.C. $8 \$ 78 s(a)(1)$ and $78 \mathrm{~s}(\mathrm{a})(3)(1964)$. 
floor traders ${ }^{27}$ and short sales, stop-loss orders and manipulative or deceptive devices..$^{28}$ This direct rulemaking authority supercedes exchange self-regulation.

(3) The SEC can under Section 19(b) "alter or supplement" an exchange's rules, if, after appropriate request, the exchange does not make needed changes on its own. ${ }^{29}$ This authority, granted for "the protection of investors, ... to insure fair dealing ... [ [and] to insure fair administration," 30 extends to thirteen areas of exchange operations, from trading hours, to financial responsibilities of members, to reasonable commission rates. ${ }^{31}$

There has been minimal formal use of the Exchange Act's Section 11 rulemaking and Sections 19(a) and 19(b) oversight powers, ${ }^{32}$ and thus minimal judicial scrutiny of required procedures. But Section 11 seems to contemplate some "formalization" of procedures in its rulemaking authority. Because the Section applies to all exchanges and has a "public interest" statutory guideline, it seems to require "notice of proposed rulemaking" and "opportunity to participate in the rulemaking through submission of written data, views or arguments" as later codified by the Administrative Procedure Act. ${ }^{33}$ Sections 19(a) and 19(b) speak specifically of "appropriate notice and opportunity for hear-

27. Securities and Exchange Act of 1934 § 11, 15 U.S.C. § 78k (1964).

28. Securities and Exchange Act of 1934 \$ 10, 15 U.S.C. $\$ 78 \mathrm{j}$ (1964).

29. Securities and Exchange Act of 1934 \$ 19(b), 15 U.S.C. $\S 78 \mathrm{~s}(\mathrm{~b})$ (1964).

30. Securities and Exchange Act of 1934 19(b), 15 U.S.C. $\$ 78 s(\mathrm{~b})$ (1904).

31. This oversight extends to "such matters as (i) safeguards in respect of the financial responsibility of members and adequate provision against the cvasion of financial responsibility through the use of corporate forms or special partnerships; (2) the limitation or prohibition of the registration or trading in any security within a specificd period after the issuance or primary distribution thereof; (3) the listing or striking from listing of any security; (4) hours of trading; (5) the manner, method, and place of soliciting business; (6) fictitious or numbered accounts; (7) the time and method of making setulements; (8) the reporting of transactions on the exchange and upon tickers maintained by or with the consent of the exchange, including the method of reporting short sales, stopped sales, sales of securities of issuers in default, bankruptcy or receivership, and sales involing other special circumstances; $(9)$ the fixing of reasonable rates of commission, interest, listing, and other charges; (10) minimum units of trading; (11) odd-lot purchases and sales; (12) minimum deposits on margin accounts; and (13) similar matters." Securities and Excliange Act of 1934 \$ 19(b), 15 U.S.C. $\$ 78 s(b)$ (1964).

32. Only once has the SEC suspended or withdrawn an exchange's registration under Section 19(a). That was in connection with a small exchange dealing in speculative mining stocks, whose officials repeatedly violated the Exchange Act and the Sccurities Act of 1933 . Securities Exchange Act Releases Nos. 6865 (July 30, 1962) and 7870 (April 22, 1960), aff'd. San Francisco Mining Exchange v. SEC, 378 F.2d 162 (9th Cir. 1967). The SEC's non-use of Section 19(a)(3) authority to suspend or expel securities exchange officials is discussed in L. Loss, Securities Regulation 1173 (2d ed. 196I), 3136 (Supp. 1969). Non-use of these sanctions may be accounted for by their drastic nature; as the Speciat. Srudr, supra note 8, pt. 4, at 698, puts it, "the "big stick' provided here may be too big."

Only twice has the SEG promulgated rules under Section 11. See pp. $819.821 \mathrm{in} / \mathrm{ra}$. And only twice has the SEC formally used its Section 19(b) authority; on only one of those occasions did it go through a full 19 (b) proceeding. See p. 824 infra.

33. See Administrative Procedure Act $\S 4,5$ U.S.C. $\S 1003$ (1964). 
ing." ${ }^{34}$ Although 19(b) talks of notice and hearing only after an exchange turns down SEC suggestions for rule changes, "elementary fairness" may require the opportunity for other interested parties to be involved in the decision-making process even when an exchange complies with SEC requests voluntarily. ${ }^{35}$

\section{Bargaining Environment of the Sixties}

The SEC has been actively involved in overseeing several New York Stock Exchange practices during the past decade. A close relationship between Exchange officials and SEC commissioners and staff members $\mathrm{s}^{\mathrm{ju}}$ has been used to bargain compromise solutions. There have been private meetings at SEC headquarters in Washington and at inclustry conventions, ${ }^{37}$ daily telephone calls and communication at social gatherings. ${ }^{38}$

During the 1950's there was little SEC intervention in New York Stock Exchange practices. ${ }^{39}$ Although the Exchange Act had given the SEC broad authority, it had not been used, either formally or informally. ${ }^{40}$ Two factors in the bargaining environment explain much

34. Securities and Exchange Act of $1934 \S \S 19(\mathrm{a})$ and $19(\mathrm{~b}), 15$ U.S.C. $\$ \S 78 s(\mathrm{a})$ and $78 s$ (b) (1964). Noting that there may be no answers until the Exchange challenges the SEC in court, former SEC director of Trading and Exchanges Philip Loomis listed sontc questions left open by the statutory language of Section 19(b) in Loomis, The Sccurilies Exchange Act of 1934 and the Investment Advisers Act of 1940, 28 GEo. WASH. L. RwV. 214, 223 (1959): "Is the power substantially limited to the twelve enumerated areas, or do the references to 'such matters as' and 'similar matters' give the Commission a substantially unrestricted jurisdiction? The statute seems to contemplate that the Commission shall formulate its proposed changes in rules before the hearings, rather than, as would seem more logical, after the evidence is in. How specific must the 'specified changes' be? Arc the issues at the hearing limited to the desirability of adopting the specified changes proposed by the Commission, or do they include the desirability of any changes in the area in question? Can the Commission, after hearing the evidence, require the adoption of rules substantially different from those originally proposed? Does an exchange have power under Section 6(c) to modify rules imposed by the Commission under Section 19(b), and does this depend upon whether the Commission alters the rules by regulation or by order?" Perhaps, even more fundamental is the unanswered question, must the Commission hold a hearing as part of a $19(\mathrm{~b})$ proceeding. Loomis seems to assume so here, but in the second use of 19(b) in 1964, none was held. See p. 824 infra.

35. See pp. 839-841 infra.

36. SEC oversight of Exchanges is handled at the staff level by the Division of Trading and Markets (before 1963 called Division of Trading and Exchanges).

37. The SEC chairman annually addresses the Florida get-together of the Investment Bankers Association. L. KoHLMEIER, THE Regulators 70 (1969).

38. When he was chairman of the SEC in the early 1960's, however, William Cary refused to attend industry cocktail parties in Washington. I Il.

39. Taking over as SEC Chairman in 1961, William Cary found, "The SEG has rather broad and general powers which it had not adequately excrcised." W. CANY, stepra note 20 , at 69. Commenting on the SEC's failure to use its $19(\mathrm{~b})$ authority, Sidncy Robulns, chief economist of the Special Study, concurred: "[A]t least during the period intervenitig: between the early years after its inception and those of the Special Study, the Commission does not appear to have been a formidable overseer of its self-regulatory responsibilitics." S. Robbins, The SEcurities Markets, OpERations and Issues 118 (1966).

40. The informal regulatory process to be described here as it operated in the 1960's is 
of the SEC's new activism in the 1960's: the "scandal syndrome" and the antitrust threat. The securities industry is prone to periodic scandals; ${ }^{41}$ scandals have given impetus for more vigilant government regulation throughout the past 40 years. ${ }^{42}$ Speculative fever and market collapses on the American Exchange in $1959^{43}$ awoke the SEC from its lethargic regulation of the $1950^{\prime} \mathrm{s}^{44}$ and precipitated Congressional authorization for the SEC's Special Study of Securities Markets. ${ }^{45}$ Reaction to the scandals created pressure for the SEC to intervene actively to reform exchange practices. ${ }^{46}$ Even without scandals the SEC probably would have been pushed into more vigilant regulation by the threat of antitrust suits against the Exchange. Since 1963 when the Supreme Court in Silver v. New York Stock Exchange declared antitrust exemption is to be implied for anticompetitive Exchange practices "only to the

similar to that used by SEC officials in the 1950's, as described by a forner SEC Commissioner, A. Orrick, Organization, Procedures and Practices of the SEC, 28 GEO. WASIl. L. REv. 50, 72 (1959); but the aggressiveness of the SEC within that process in the 1950's wis much reduced.

41. Fraudulent manipulation followed by drastic drops in the market, great losses due to negligence in fiduciary responsibilities to investors, and revelations of insider finagling are common causes of scandals on Wall Street.

42. Scandals following the boom period of the 1920's provided impetus for passage of the Exchange Act in 1934. R. DEBEDTs, supra note 3, at 12, 18, 21 and 28. In the late 1930's the SEC forced major changes in internal governance at the New York Exchange with the help of revelation of criminal activities by former Exchange President Richard Whitney. 2 L. Loss, SecurTtIes Regulation 1181 (2d ed. 1961). Revicwing the history of government regulation of securities markets, DeBedts concludes, "Only one thing renains in common in several centuries of legislative efforts to regulate ulie cxploiter of the investor. Inevitably such attempts come about only when the disastrous results are seen in retrospect." Supra, at 1 .

43. For a full description of the Amex scandal, see the SEC staff report, reprinted in SPECIAL Study, supta note 8 , pt. 4 , at 755.806 .

44. The shock of the revelation of improprieties at the American Exchange and the great change thus caused in the political environment at the SEC is shown in the sharp contrast between former SEC Director of Trading and Exchanges Loomis comment in 1959 that, since the Whitney scandal, "the significant exchanges have developed a high sense of public responsibility and a strong desire to operate in a manner which merits the confidence of the public," Loomis, supra note 34, at 223; and the SEC staff's conclusion in 1963: "The picture at the American Stock Exchange prior to January 1962 was a coniplete distortion of the self-regulatory system embodied in the Exchange Act," Sprcial. Srtor, supra note 8 , pt. 2 , at 583 .

45. N.Y. Times, May 6, 1962, § 3, at 1, col. 5; and N.Y. Times, June 28, 1961, at 51, col. 3. Former SEC Chairman Cary lists as events leading to the Special Study the turbulent market, prevalence of hot issues, extravagant price-earnings ratios, high rates of "fails" to deliver of stock certificates, criminal references to the Justice Deparument at an all-time high, and, "most dramatic," the investigation of the American Exclange. W. Cars, sipra note 20, at 71 . Coming out of the Special Study have been the 1964 ainendments to the Securities Act and to the Exchange Act, a basis for improved selling practices, qualification standards for broker-dealers not members of registered assaciations, new rules for specialists and floor traders, and more and better quotations for the over-the-counter market. W. CARY, supra note 20, at 75-76.

46. The cycle of intense regulatory activity followed by periods of quiescence is decmed a "political fact" in Fick, supra note 3 , at 299 . After the scandal is over, "there is a newly" evolved status quo. . . . Under normal condtions . . . private management is incvitably the dominant organizing force." Jaffe, The Limils of the Administrative Process: A Recualuation, 67 HARV. L. REv. 1105, 1109 (1954). 
extent necessary to protect the achievements of the Exchange Act," 47 the SEC and Exchange have realized absence of SEC surveillance and approval of Exchange anticompetitive practices ${ }^{48}$ will leave the Exchange open to possible convictions for antitrust violations. ${ }^{40}$

The three SEC/NYSE disagreements described below were all precipitated by either the scandal syndrome or the antitrust threat. ${ }^{50} \mathrm{Im}$ petus for vigilant SEC oversight came largely from interested parties other than the SEC and the Exchange; public and Congressional indignation after scandals and litigation threats from the Justice Department and non-members of the Exchange emphasized dissatisfaction with existing Exchange practices. However, resolution of issues was made predominantly without the involvement of these interested parties. The SEC and Exchange were pushed to the bargaining table by outside forces, but other interested parties were then deprived of access to the decision-making process.

\section{The Informal Bargaining Process in Action}

Three SEC/NYSE disagreements over the past decade have been chosen to demonstrate the workings of the informal bargaining process. The descriptions provide a background for evaluating whether it would be desirable to formalize the regulatory pattern through use of any of the seven instruments for structuring discretion.

Description of the chronology and of the forces shaping resolution of

47. 373 U.S. 341,357 (1963) rehearing denied 375 U.S. 870 (1963). Silver, a non-member of the Exchange, sued after his wire connection had been cut off, charging antitrust violations by the Exchange in boycotting him. In an attempt to reconcile the antitrust laws with the Exchange Act, Justice Goldberg found there might be justification for Exchange regulation of ticker service to non-members, but held the Exchange's act of cutting off Silver's service without notice or hearing was unjustified and served no purpose of the Exchange Act. The Justice read due process procedures into the Exchange Act, but did not strike down any Exchange anticompetitive practices; no other court has yet to strike down an Exchange practice under the antitrust laws.

48. Among Exchange practices which would violate antitrust principles worc it not for the possibility of an implied exemption because of SEC oversight are collective sctting of commission rates, restrictions on with whom members can trade, and limitations on thic number of, and character requirements for, members of the Exchange. 5 L. Loss, Srcuritt's REGULATION 3156 (Supp. 1969).

49. The Exchange Act grants exemption from antitrust legislation to the over-the. counter market organization, the National Association of Securities Dealers, Sccurities and Exchange Act of $1943 \$ 15 A(n)$, 15 U.S.C. $\$ 780-3(n)(1964)$. Without such an explicit exemption, the securities exchanges must rely on implicd exemption. Sec Thrill Securities Corp. v. New York Stock Exchange, 433 F.2d 264 (7th Cir. 1970); Eisen v. Carlisle and Jacquelin, 391 F.2d 555 (2d Cir. 1968); Kaplan v. Lehman Bros., 371 F.2d 409 (7th Clr. 1967) cert. denied, 389 U.S. 912 (1968); Klebanow v. Funston, 35 F.R.D. 518 (1961).

50. The floor trading dispute grew out of the agenda of issucs spelled out in the SPECIAL Study, supra note 8, pt. 2, at 213-25. Revision of oft-floor trading rules was sparked by threat of an antitrust suit. See p. 822 infra. The commission rate structurc review has involved an attempt to construct an antitrust exemption for Exchange price fixing. Sec p. 826 infra. 
these issues will demonstrate the lack of openness to public scrutiny and of policy articulation. Often the SEC has suggested changes to the Exchange, the Exchange has agreed, and there has been no public announcement. ${ }^{51}$ On other issues, public announcements have been made only after the SEC and Exchange have bargained out differences alone. ${ }^{52}$ When changes in Exchange practices have been announced, there has often been no articulation of policies, reasons and findings.

Description of the informal bargaining process will emphasize that, rather than describing a desired modus operandi for the SEC, the statutory provisions are merely being used as an arsenal of weapons through which the SEC has bargaining leverage at the informal level. Section 11 rule-making authority has been used not as a procedure for the SEC to find the best regulations for floor trading but as a bargaining threat, and then, as a formal means of announcing a close-door bargaining outcome..$^{53}$ Section 19 (b) authority is not a procedure which the SEC has used to update and reform Exchange rules after notice and hearings, but a threat which the SEC brandishes to push Exchange reform, or a formal announcement procedure which is used by the Exchange to shift pressure from itself to the SEC by making it appear that the SEC is forcing Exchange reform. ${ }^{\text {st }}$

\section{(1) Floor Trading}

The SEC's first and only use of its Section 11(a)(1) authority to prescribe rules for exchange floor traders was in 1964.55 Floor traders are Exchange members who trade for their own accounts while personally present on the Exchange floor. They have advantages over other investors because of on-the-spot contact with trading ${ }^{50}$ and can cause manipulated market fluctuations. ${ }^{57}$ The potentially harmful effect of these market insiders on fair and honest markets was recognized as early as 1934 when the original draft of the Exchange Act prohibited floor trading. ${ }^{58}$ The prohibition was rejected by Congress in favor of Commission authority to regulate, or, if necessary, abolish, floor trading. ${ }^{53}$

51. See p. 831 infra.

52. See pp. $820,823-24$ infra.

53. See text accompanying notes 55-69 infra.

54. See pp. $822-825$ infra.

55. Securities Exchange Act Release No. 7290 (April 9, 1964).

56. Id. at 4-6. SPECIAL STUDY, supra note 8, pt. 2, at 208.13.

57. SPECIAL STUDY, supra note 8, pt. 2, at 213.25.

58. S. 2693 and H.R. 7852, 73d Cong., 2d Sess. (1934) § 10.

59. Statutory prohibition of floor trading was replaced by Section $11(a)$ authority for SEC rule-making because, according to Congressman Lea, Congress was unsure, in light of its 
Although the SEC conducted no less than 15 studies of floor trading abuses, ${ }^{60}$ not until 1964 did it adopt any rules to protect investors. The Special Study's condemnation of floor trading brought the issue to the fore again in the early $1960^{\prime} \mathrm{s} .{ }^{61}$ Beginning in the summer of 1963 , SEC and Exchange officials held private negotiations on altering floor trading rules. Not until the SEG broke off the meetings in March 1964 were the public and other members of the investment community apprised of the nature of the SEC/NYSE dispute. ${ }^{62}$ Public hearings and an opportunity for involvement of other interested parties in the regulatory process appeared imminent; ${ }^{63}$ but through "purely private and personal negotiations," the SEC and Exchange reached a compromise, which allowed some floor trading to continue. ${ }^{64}$ Only after announcement of the compromise was public comment solicited.65 Two months

inexperience in securities regulation, of the ramifications of floor trading; and because "where we gave the Commission the power, it would be a flexible power. If the Conl* mission finds a mistake has been made, it can readily change its rules to more favorable ones and thus accomplish the purpose of Congress." 78 CoNG. REC. 7862 (1934).

60. Securities Exchange Act Release No. 7290 (April 9, 1964) at 4-6. In 1985 the Commission suggested that the exchanges adopt rules governing floor trading. Nothing was done, and in 1936 the Commission suggested the segregation of floor trading from floor brokerage functions; but, again, the suggestions were not carried into effect. Another major evaluation in 1945 found exchange regulation of foor trading inadequate, and the Commission tentatively determined to abolish floor trading. But "after considering the unatter" and holding conferences with the Exchange," nothing was done by the agency after "repeated assurances" of self-regulation. Id. at 7. In the 1945 negotiations the SEG was discouraged from abolishing floor trading through the "covert" intervention of President Truman. $L$. KOHLMEIER, supra note 37, at 41 . As a result of the 1945 negotiations, the Exchange was given time to develop adequate rules on floor trading, but the rules adopted as a incans of curbing abuses were steadily eroded. Special StuDY, supra note 8, pt. 2, at 233.37. As the SEC concluded in announcing Rule 1la-1, "therc has been no time in the past thirty years when the Commission, which has the statutory responsibility, has been in a position to make a finding that exchange regulation has satisfactorily solved the problems of floor trading." Securities Exchange Act Release No. 7290 (April 9, 1964) at 9.

61. SPECLAL STUDX, supra note 8, pt. 2, at 241-42. Following the Study, a letter of July 23, 1963 from the SEC to Congress promised a proposal abolishing floor trading would be developed "[i]n light of the very serious and basic problems" to be solved "unless those exchanges demonstrate that its continuance would be consistent with the public interest." Securities Exchange Act Release No. 7290 (April 9, 1964) at 9.

62. N.Y. Times, Dec. 13, 1963, at 23 , col. 4 , noted that the SEC regular staff was taking a much more cooperative attitude on seeking a compromise with the Exchange than had the Special Study staff; and N.Y. Times, March 16, 1964, at 47, col. 8.

63. N.Y. Times, March 16, 1964, at 47, col. 6 and March 17, 1964, at 45, col. 5 .

64. N.Y. Times, June 8, 1964, at 41 , col. 2. Only two weeks before announcement of the compromise solution, Exchange President Funston followed up a visit to President Johnson with a private discussion with SEC Chairman Cary. N.Y. Times, March 26, 1904, at 49, col. 2. Although floor trading was a topic of the Funston-Cary discussion, the former SEC chairman claims it was not even mentioned at the White Housc. W. CARY, supra notc 20, at 17-18.

65. Securities Exchange Act Release No. 7290 (April 9, 1964) at 14. Rule 11a-1 did not prohibit floor trading. It limited such trading to certain special circumstances or transactions in conformance with an exchange plan "designed to eliminate floor trading activities which are not beneficial to the market." The simultancously announccd New York Stock Exchange plan set up a category of floor traders known as registered traders, who must meet minimum capital requirements $\$ 250,000$ above their capital required for other trading, who are prohibited from floor trading and trading for brokerage activities 
later, without discussion of any comments received by the SEC, new SEC and Exchange rules were adopted. $0^{\circ 6}$

Although the public interest in a fair and honest market may have been the guiding principle for SEC officials seeking floor trading changes, three political factors provided bargaining leverage for the agency. The Exchange did not want public hearings on floor trader abuses; it had received black eyes in previous hearings and was willing to give in to avoid repetition. ${ }^{\text {it }}$ Secondly, many Exchange members did no floor trading themselves and exerted pressure to dispense with the embarrassing issue as quietly and expeditiously as possible. ${ }^{\text {is }}$ And third, the SEC's "trump card" was played with its disclosure that the number two man on a private study done for the Exchange had resigned after his finding, that floor trading did "irreparable harm" to the auction market, was suppressed by the Big Board. ${ }^{\circ}$

in the same security on the same day, who must yield to trades from off-floor, and who must make stabilizing trades 75 per cent of the timc. Id. The compromise involved in this rule is evident; the Exchange originally wanted only a 60 per cent stabilizing requirement, the SEC wanted 85 per cent. N.Y. Times, March 16, 1964, at 47, col. 6 .

66. Securities Exchange Act Release No. 7330 (June 2, 1964). For a sinilar study of SEC inaction over many years, followed by a furry of concern after the Special Study found abuses, see the description of the promulgation of SEC Rule $11 b-1$ dealing with specialists, in H. Bartell and R. Robinson, Uneasy Partnership, SEC/NYSE, 43 HARV. BUS. REV. 76, $81-83$ (1965) and $\mathrm{N}$. Wolfson and T. Russo, The Stock Exchange Specialist, An Economic and Legal Analysis, 1970 DukE L.J. 707. From 1937, when the SEC dereloped its Saperstein Interpretation to guide the Exchange in self-regulating specislists, until the 1962 Amex report, the Commission made no formal pronouncements on specialists, N. Wolfson, sufra at 721. The Special Study, after a finding of need for a "number of inportant, specific improvements in specialist practices and in regulatory concepts and methods." called for SEC action under Section 11(b). SPECIAL STUDY supra note 8, pt. 2, at 167-71. The SEC promulgated a rule after private negotiations with the New York and Amcrican exclianges. $\mathrm{N}$. Wolfson, supra at $724-25$. The inaction of the SEC over 25 jears came despite existence of $11(b)$ authority and H.R. REP. No. 1383, 73d Cong., 2d Sess. 14-15 (1934), accompanying the Exchange Act, which said: "Inasmuch as the stock exchanges objected to the laying down of any statutory rule governing specialists, their suggestion has been adopted of giving the Commission effective power to control the activities of specialists and to experiment with various devices of control."

67. N.Y. Times, April 9, 1964, at 41, col. 7. See also W. CARr, supra note 20, at 45.

68. N.Y. Times, March 25, 1964, at 53, col. 6; April 6, 1964, at 45, col. 2; and April 9, 1964, at 1, col. 1. In 1964 at the time of the rule changes, 400 members of the Exchange floor traded; only 35 of these made floor trading a primary activity. Floor trading accounted for only 2.1 per cent of Exchange volume. Securities Excliange Act Release No. 7290 (April 9, 1964) at 1.

The SEC was aware of divisions at the Big Board. Concerned with the disproportionate voice of floor professionals, who had 10 per cent of the business and 60 per cent of the seats on the Exchange Board of Governors, the SEC hoped to use the floor trading issue to "foment an internal revolt" against any remaining "private club" vestiges at the Exchange. N.Y. Times, April 6, 1964, at 45, col. 2. See also H. Crossland and R. Sehr, The Gods of the Miarketplace: An Examination of the Regulation of the Securities Business, 48 B.U. L. REv. $515,548-50$ (1968).

Use by the SEC of dissidents within the Exchange to help reform the institution is an old technique. See DEBEDTS, supra note 3, at 145-52, on Chairman Landis" "cultivation" of Exchange liberal members during the mid-1930's to challenge the governance structure of the Big Board.

69. N.Y. Times, April 6, 1964, at 45, col. 2; and April 12, 1964, § 3, at 1, col. 1. 


\section{(2) Off-Floor Trading}

The SEC used its Section 19(b) power to alter an Exchange rule for only the second time in its history in $1966^{70}$ to change off-floor trading practices. Exchange Rule 394 limited severely the right of members to execute trades for customers with non-member market-makers, even if a better execution could be made off of the Exchange floor. ${ }^{71}$ This limitation on trading was questioned severely by the Special Study ${ }^{72}$ and was open to attack as an antitrust violation. By restricting those with whom members could deal, the rule established a group boycott..$^{\text {t3 }} \mathrm{M}$. A. Schapiro, a New York Exchange non-member, threatened antitrust action unless the SEC rescinded or modified Rule $394 . .^{74}$ In response to Schapiro's request for 19(b) action, the Commission prepared a staff study on off-floor trading. Secret testimony was taken from Exchange members and representatives of regional exchanges and third market firms. ${ }^{75}$ The study condemned Rule 394 for thwarting purposes of the Exchange Act and recommended loosening of Exchange rules to allow more off-floor trading. ${ }^{78}$

70. See p. 824 infra for a discussion of the first use of Section 19(b).

71. SEC STAFF STUDY, IN THE MATtER OF RULES, Regulations AND Practices Ritating to OfF-BoARd Trading, Conclusions and Recommendations (1965) [hereinafter cited as STAFF STUDY ON OFF-BOARD TRADING]. The Study found, "[S]ubsequent interpretations of ... Rule 394, filed originally with the Commission [in] 1957, have progressively prevented member firms from executing agency offers off of the floor of the Exchange or from cngag. ing in any trade off the Exchange for their own account ..... [T]here seems little question but that executions in the third market, particularly on block trades, would in many circumstances result in better dollar price for the institutional investor." Id. at 1-2.

72. SPECIAL Studx, supra note 8, pt. 2, at 242-46. The interference of Rule 394 with customers receiving the best possible execution from their broker conflicted with the SEC policy announced in Edison Electric Illuminating Co. of Boston, 1 SEC 909, 913 (1936) that a "well-governed exchange recognizes limits to its operations as an automatic auction market and should ... recognize and enforce the duty of a broker to get the best price for his client, even though that price is only obtainable off of the floor of the cxchangc." "The interference also conflicts with the SEC action in its first 19(b) proceeding. The Rules of the New York Stock Exchange, 10 SEC 270 (1941), where the SEC ordered the Bif Board to eliminate rules preventing members from trading on regional exchanges in stocks also listed on the New York Exchange.

73. See Fashion Originators Guild of America, Inc. v. FTC, 312 U.S. 457 (1941); Radiant Burners, Inc. v. Peoples Gas, Light \& Coke Co., 364 U.S. 656 (1961); Klor's Inc. v. Broadway. Hale Stores, Inc., 359 U.S. 207 (1959).

74. Schapiro presented to the Commission a copy of the antitrust complaint, which he had planned to file in 1965 when he was pushing the SEC to take action on off-floor trading rules, during the 1968 SEC hearings on the Exchange commission rate structurc. Official Transcript of Proceedings Before the Securities and Exchange Commission Rate Structure Investigation, testimony of M.A. Schapiro 3924-25 and Schapiro Exhibit 2 (1968) [hercinafter cited as SEC Rate Structure Investigation]. Schapiro, as a non-member of the Exchange and as a third market dealer in bank stocks, was concerned by the 1965 listing of Clitse Manhattan common stock on the New York Exchange. That listing, he feared, would interfere with his dealings with New York members who would be prohibited from trading in Chase stock with him by Rule 394. Securities Exchange Act Release No. 7954 (Sept. 16, 1966) at 12, refers to Schapiro's request for 19(b) action on Rule 394 without naming him. 75. Id. at 2.

76. StafF StUdy on OFF-BOARD Trading, supra note 71, at 3.5, found Rulc 394 "was 
Despite the outside interest of Schapiro, and the major importance to many non-members of the New York Exchange, resolution of changes in Rule 394 was made in a series of private negotiations between the SEG and Exchange. ${ }^{77}$ Only the Exchange was given a copy of the Conclusions and Recommendations of the Staff Report. ${ }^{\text {is }}$ They were not shown to any of the persons who had testified during their preparation, other than Exchange officials. ${ }^{79}$ Neither the body of the staff report nor the testimony taken in its preparation have ever been made public. ${ }^{80}$

geared to the economic interests of Exchange members," and "in many cases . . . thwarted rather than furthered the purposes of the Exchange Act."

77. Some portion of the private negotiations between the SEC and the Exchange an be pieced together through a series of fifteen letters-eight from the SEC to the Exchange and seven from the Exchange to the SEC-dated from Nov. 29, 1965, to Oct. 3, 1907. The letters were turned over to Schapiro on Aug. 5, 1968 after his request for them and for the Staff Study on Off-Board Trading. The Ietters [hercinalter cited as SEC/NYSE Rule 394 Correspondence] are contained in Appendix $\mathrm{H}$ of Plaintiff's Reply to Defendant's Memorandum in Opposition, M.A. Schapiro and Co. v. SEC, Civil No. 2243-70 (D. D.C., filed Sept. 25, 1970) (See note 88 infra).

The letters provide insight into the familiarity of the SEC/NYSE relationship. Exchange President Funston's letter of Nov. 29, 1965 to SEC Chairman Cohen sajs, the "ball rests with you" in relation to resolution of the Rule 394 issue. Cohen's letter of Dec. 22, 1965 mentions the "fruitful discussions" between staffs of the SEC and Exchange. The Nov. 29, I965 Funston to Cohen letter emphasizes the personal nature of the relationship: “As jou know I am going into the hospital today for ten days .... I regret that I have to be away at this time but I guess one can't pick and choose when one goes to the hospital."

Cohen's letter of Dec. 22, 1965 to Funston summarizes the essence of the bargaining process: "As you know, these matters have been considered by the Exchange and the Commission for many months and though re expect ultimate implementation may require communication with other self-regulatory institutions and other affected parties, ve hope that these matters can be moved forward to their resolution within a reasonably short period of time." (Emphasis added.)

78. SEC/NYSE Rule 394 Correspondence, supra note 77, letter from Cohen to Funston of Dec. 22, 1965. After the Exchange received the Staff Study Conclusions and Recommendations, it submitted to the SEC a suggested rule change which the SEC found inadequate, as detailed in Cohen to Funston letter of MIay 12, 1966. The SEC suggested its own approach. Drafts of proposed rule changes then went badk and forth between SEC and Exchange, letter of Aug. 15, 1966 from SEC Division of Trading and Mrarkets Associate Director Eugene Rotberg to Exchange Vice President Alger Chapman, Jr.

79. The SEC did not make the Staff Study Conclusions and Recommendations public, except for sending a copy to the Exchange. Schapiro released them to the public alter he obtained them from the SEC two years later. (See note 74 supra.) Schapiro placed the Conclusions in the record at the 1968 Rate Investigation hearings. SEC Rate Structure Investigation, supra note 74, Nov. 7, 1968, Schapiro Exhibit 1.

80. Schapiro has sued the SEC under the Freedom of Information Act of 1965, 5 U.S.C. \$ 552, to produce the full Staff Study on Off-Board Trading and the transeripts of interviews and other documents the SEC staff used in preparation of the Study. M.A. Schapiro and Co., Inc. v. SEC, Civil No. 2243-70 (D. D.C., filed July 29, 1970). The SEC has refused to turn over the requested report and testimony on grounds that they are exempted from the Freedom of Information Act as (1) intra-agency memoranda, (2) matters related to examination, operating or condition reports prepared for use of an agency responsible for regulation or supervision of a financial institution, and (3) investigatory files compiled for law enforcement purposes. Defendant's Supplemental Memorandum, M.A. Schapiro and Co. v. SEC supra, filed Oct. 1, 1970.

Release of the entire Staff Study has also been requested by the Justice Department. RESPONSE OF THE U.S. DEPT. OF JUSTICE TO SEC RELEASE 8791 (March 00,1970 ), at 17. The SEC denies that the full text of the Staff Study was shown to the New York Stodk Exchange at the time of the SEC/NYSE negotiations in 1965, Defendant's Supplemental Mlemorandum supra, at note 7; but see letter of Dec. 22, 1965 from Cohen to Funston, SEC/NYSE Rulc 
Only after SEC/NYSE bargaining had reached a compromise were the new SEC and Exchange rules on off-floor trading revealed to the public, and comments solicited on them. ${ }^{81}$ One month later, with no discussion of the eight comments received by the SEC, the new rules were adopted. ${ }^{82}$

SEC approval of the new off-floor trading rules was clothed as a $19(\mathrm{~b})$ request to the Exchange. ${ }^{83}$ There was no need for the formal request, as the SEC and Exchange had bargained to a compromise before the request was made. Operationally, the use of a 19 (b) request after, rather than before, resolution of the issue, may have been little different from the first use of 19 (b) in 1940, because the threat of 19(b) authority loomed in the background throughout SEG/NYSE bargaining. But, procedurally, this use of 19 (b) was quite different. In 1940 the SEC had first formally requested a rule change; after the Big Board refused to comply, the Commission held hearings, issued an opinion and ordered the change. ${ }^{84}$ In 1966, the Exchange asked the SEC to clothe the change in off-floor trading rules as a 19(b) request, probably to establish a formal groundwork for antitrust exemption and to ease the Exchange's relations with members unhappy with the reform. ${ }^{85}$

394 Correspondence, supra note 77: "We understand that you have had a thorough dis. cussion with our staff of the underlying materials which form the basis for such conclusions and recommendations" on Rule 394 .

81. Securities Exchange Act Release 7954 (Scpt. 16, 1966). The proposed Exchange Rule 394 (b) provided for a member soliciting a non-member market maker for ail off-floor trade if the member had first made a diligent effort to make a satisfactory cxecution on the floor and had offered to execute the trade at the same price on the floor immediately prior to the off-floor execution. Commission Rule 19(b)-1, announced simultaneously, set requirements for non-member market makers who may be solicited for off-floor trades.

Although the SEC asked for comments on the proposed rules, there were no public hearings. The Exchange, fearing the loss of public confidence should hearings be held, wats willing to compromise on the issue to avoid public airing. Loomis, The SEC Has a Litlle List, 75 ForTuNE, Jan. 1967, at 111, 113.

82. Securities Exchange Act Release No. 7981 (Oct. 20, 1966). The eight comments the SEC received in reply to Release No. 7954, stipra note 81 , included one from Schapiro, three from other non-member broker-dealers complaining that the proposed changes did not go far enough in allowing off-floor trading, a plea from the Midwest Stock Exchange not to apply Rule 19(b)-1 to it, and a request from the Philadelphia.Baltimore-Washington Exchange to require New York members to check for possible exccutions on regional exchanges before trading with third market dealers. Letters on file at the SEC in Washington.

83. Securities Exchange Act Release No. 7981 (Oct. 20, 1966).

84. The SEC action was sparked by the February 1940 Exchange decision to enforce its constitutional ban on member trading on regional exchanges in stocks also listed on the New York Exchange, so-called multiple trading. The Commission studied the ban from April to October before requesting reform from the Exchange. After no compliance, the Division of Trading and Exchanges prepared a full report for the Commissioners, who then made the formal 19(b) request. After the Exchange said no, hearings before a trial examiner, a trial examiner's report, filing of briefs, Commission consideration and an opinion followed before the SEC ordered the rule change ending the ban on multiple trad. ing. In the Matter of the New York Stock Exchange, 10 SEC 270, 272.74 (1941).

85. 5 L. Loss, Securities Regulation 3168-69 (Supp. 1969). 
Despite Exchange President Funston's statement that the Big Board was a "reluctant partner" in the "sweeping change" in off-floor trading, ${ }^{86}$ new Rule 394(b) has almost no change at all. Procedures for offfloor trading remain onerous and are little used. ${ }^{.7}$ Despite former SEC Chairman Cohen's promises, ${ }^{88}$ the SEC has done little to require the Exchange to make the new rule achieve its professed purposes. ${ }^{53}$

\section{(3) The Commission Rate Structure}

The SEC is specifically charged with oversight of exchanges' "fixing of reasonable rates of commission" under Section 19(b).80 Despite this responsibility, the New York Stock Exchange was able to raise its commission rates four times between 1934 and 1958 with nary a whisper of public protest from the SEC. ${ }^{91}$ In 1959 it seemed a bolt out of the blue when the SEC announced, after secret bargaining with the Exchange, a small rollback in the Exchange's 1958 rate increase. ${ }^{22}$ But when the Ex-

86. N.Y. Times, Sept. 18, 1966, § 3, at 1, col. 8 .

87. Letter from Cohen to Funston of Aug. 23, 1967, SEC/NYSE Rulc 394 Correspondence, supra note 77: "We must emphasize that rule 394 was designed to malsc it possible for a member to execute off the floor if he could bet a better price. The interpretation you have given this rule may make it impossible as a practical matter for him to do so." According to an Exchange newsletter, from Nov. 7 to Dec. 30, 1960, Rulc 391 was used Iess than once a day. N.Y. Times, Jan. 12, 1967, at 52, col. 6. Sec also Wall St. Journal, Feb. 14, 1967, at 2, col. 3. Use of Rule 394(b) has increased little since. N.Y. Times, MIa' 13, 1970, at 61 , col. 5 .

88. Cohen told the American Management Association on Nov. 16, 1966, that the SEC had already made "an important first step" in promoting off-floor trading, and "we plan to exercise special diligence in this area ... to determine whether the change is achieving its purpose." Quoted in Rule 39f(b) on Probation, BANK STock Quartens,, Dec. 1966 , at 2.

89. Despite the minimal use of Rule $394(\mathrm{~b})$, it stands today as amended in 1960 except for small modifications which reduce the paperwork requirements and grant more Exchange floor officials authority to approve going off-floor. Exchange officials admit these changes did not alter the substance of the rule. N.Y. Times, MIay 13, 1970, at 61, col. 5 . Exactly why the SEC has not followed through on implementation of 394(b)'s purposes, as stated when it was adopted, is not clear. The StafF STUdy on OfF-BOArd Tradice, supra note 71 , at 5-6, lists some advantages of on-board trading, including the listing of all trades on the ticker tape; but, at that time, the staff concluded, "disadiantages secm to outweigh the advantages," supra at 6 . No contradictory finding has been made by the Commission since. The informal bargaining process has allowed the SEC to push the Exchange on Rule 394 at some times while lessening the pressure at others without the necessity for either SEC or Exchange of openly articulating policy bases for such actions.

90. Securities and Exchange Act of 1934, \& 19(b)(9), 15 U.S.C. § 78s(b)(9) (1904).

91. For each rate increase, the Exchange notified the Commission of the proposal before approval; but only in 1942 did the Commission suggest any alterations in the proposal; the small alteration was accepted by the Exchange. In each instance the Exchange vis given private assurance by the SEC that it approved of the new rates. SPEcinc STuDr, supra note 8, pt. 2, at 329-33. Except for the 1942 increase, the only data upon which the SEC had to rely in giving approval was supplied by the Exchange itsclf. Supra at 342 . As a result of this non-vigilant attitude toward commission rates, "the Commission itself has never publicly articulated any views as to appropriate standards, except in the most limited respects," concluded the SPEcial Srudy, supra at 333.

92. SPECTAL STUDY, supra note 8, pt. 2, at 331-32. The Exchange membership had already approved the increase on April 3 when the SEC announced its inquiry into its reasonableness. Securities Exchange Act.Release No. 5678 (April 14, 1958). The SEC-forced 
change announced a new rate proposal in 1964, there was immediate concern with public SEC approval. ${ }^{93}$ In the six years since the previous rate proposal, the Silver decision had made the Exchange, an association of independent businessmen who fixed prices, ${ }^{94}$ aware of antitrust exposure. ${ }^{95}$ With the threat of private ${ }^{06}$ or Justice Department ${ }^{97}$ suits, the Exchange welcomed SEC investigation of the reasonableness of the proposed rate structure to establish a groundwork for antitrust exemption.

SEC dissatisfaction with profit data ${ }^{28}$ used to justify the proposed rate increases led the Exchange to shelve its 1964 rate proposal. ${ }^{00}$ By January, 1968 when it made its second proposal, concern had shifted from member firm profitability to the continued viability of a minimum rate structure with institutional participation in the Exchange market increasing. ${ }^{100}$ Institutions had devised elaborate "give-up" schemes to circumvent the fixed rate structure's lack of any volume discount as a means of reducing commission costs. ${ }^{101}$ Both the SEC and Exchange

rollback only decreased Exchange commissions by 5.3 per cent on trades with commissions between $\$ 100$ and $\$ 2400$. Securities Exchange Act Release No. 5889 (Feb. 20, 1959).

93. N.Y. Times, Dec. 31, 1964, at 1, col. 2; and N.X. Times, Jan. 28, 1965, at 35, col. 6.

94. Such price fixing had been ruled per se illegal in U.S. v. National Association of Real Estate Boards, 339 U.S. 485 (1950); U.S. v. Trenton Potteries Co., 273 U.S. 392 (1927),

The New York Stock Exchange has, since its founding in 1792, set minimum commission rates for members to charge non-members for executing trades on the Exchange. All nonmembers must pay the same commission, regardless of whether they are broker-dealers or ordinary investors. The commission rate has been based on a slicling scale determincd by money involved per round lot. The rate covers basic brokerage functions and also may pay for ancillary services such as research, wire ticker facilities and portfolio mantgement. Un* til 1968, see p. 829 infra, there was no discount for large transactions; the commission cost for a trade of 1000 shares was ten times the cost of a trade of 100 shares. Suzctat STudY, supra note 8 , pt. 2, at 294-96.

95. N.Y. Times, Nov. 19, 1964, at 57, col. 6; and Aug. 4, 1965, at 43, col. 4.

96. See the list of antitrust suits filed and threatened in N.Y. Times, Feb. 7, 1965, \& 3 , at 1 , col. 1 .

97. N.Y. Times, Aug. 19, 1963, at 35, col. 8; Feb. 7, 1965, § 3, at 1, col. 1; and Aug. 22, $1965, \& 3$, at 1 , col. 8 .

98. N.Y. Times, March 1, 1965, at 37, col. 6 .

99. N.Y. Times, July 30, 1965, at 32, col. 3. During the period between Exchange rate proposals, the SEC helped the Big Board fight antitrust litigation against the fixed ratc structure. The SEC amicus curiae brief in the 7th Circuit's adjudication of Kaplan $v$. Lehman Brothers told the court that the SEC was working on proposals for volume dis. counts and argued for the court not to meddle. N.Y. Times, Sept. 22, 1966, at 67, col. 7.

100. Securities Exchange Act Release No. 8239 (Jan. 26, 1968). By 1969, 50 per cent of all share volume and 60 per cent of all dollar value of trading of the Big Board was done by institutions. N.Y. Times, April 21, 1970, at 59, col. 6.

101. For detailed descriptions of the circuitous routes which were used by Exclintge members to give-up portions of their commissions as directed by institutional traders for whom the brokers were making transactions, see SEC Rate Structure Investigation, supra note 74, at 1372-403, 1420-54, 1601-23. The SEC had been concerned with give-up practices as early as 1966 when SEC Chairman Cohen wrote to all the exchanges and to the National Association of Securities Dealers secking ways of climinating such practices, reprinted at 112 CoNG. REc. 17,856.57 (1966). Although that letter only asked for suggres. tions on eliminating give-ups, the threat of SEC 19(b) action "was exposed beneath the velvet glove." 5 L. Loss, SEcuRities REculation 3177 (Supp. 1969). 
were worried about the drain of trading off of the Exchange necessary to implement these give-ups without violating Exchange anti-rebate rules. ${ }^{102}$ "In a step believed to be without precedent," the SEC and Exchange addressed this concern with alternative proposals for reform. ${ }^{103}$ There had been no lack of private negotiations between SEC and Big Board officials over revising the commission rate structure, ${ }^{104}$ but the end result was not the usual jointly recommended proposal. Simultaneous with Exchange announcement of its new rate proposal, the SEC proposed its own Rule $10 \mathrm{~b}-10$ to deal with give-ups. ${ }^{105}$ The unprecedented nature of the procedures continued as pressure from the

102. A common give-up procedure would be for a dual member of the Nesy York Exchange and a regional exchange to execute a trade on the regional, which did not have such stringent anti-rebate rules, allowing the Big Bosrd member to give-up part of the commission to non-member dealers the institution instructed it to compensate. These nonmember dealers often sold shares for the mutual fund making the transaction, and the fund used this device as a means of compensating them. SEC Rale Structure Imestigation, supra note 74, at 475-78, 1231-309; Securities Exchange Act Release No. 8299 (Jan. 26, 1963) at 3-4, noting that regional dollar volume increased from 6.8 per cent of all exchange volume in 1961 to 8.4 per cent in 1966.

103. N.Y. Times, March 26,1968 , at 59 , col. 5 .

104. The Exchange was considering institution of a volume discount or an approved form of commission splitting with non-members as "sweeteners" designed to gain SEC approval of a new rate structure, and had discussed such ideas with the Commission. N.Y. Times, July 30, 1965, at 32, col. 3; Dec. 2, 1965, at 60, col. 2; and Aug. 5, 1986, at 37, col. 6. Just before the January 1968 proposal was announced, Exchange President Robart Haack traveled to Washington to explain the proposal to the SEC. N.Y. Times, Jan. 3, 1968 , at 37 , col. 4 .

105. SEC Release No. 8239, at 7 (Jan. 26, 1968). More than 70 comments were received by the SEC on the simultaneously announced Exchange proposal and Rule 10b-10. More than half of the letters were from New York Stock Exchange members supporting their organization's proposals and expressing horror at Rule 10b-10. Another ten or so letters were from mutual funds, strongly endorsing volume discounts; another ten or so non-members of the New York Exchange, regional members or independent brokerdealers, said their economic livelihoods would be greatly endangered by elimination of give-ups. The only "public" comments were from two Princeton University cconomists, calling for an end to all fixed commission rates. SEC 10b-10 file frS7-319-1-2 on file at the SEC in Washington.

Recognizing that proposed Rule $10 \mathrm{~b}-10$ was "not a substitute for full re-examination of the structure and rates of Commissions on the national securities cxchanges," the SEC supported its proposals by pointing out that "if . . . a mutual fund manager has various means at his disposal to recapture for the benefit of the fund a portion of the commissions paid by the fund, he is under a fiduciary duty to do so." Securities Exchange Act Release No. 8299 (Jan. 26, 1968) at 8. Some mutual fund managers had found means to recapture commissions through mutual fund affiliates registered as broker-dealers and menbers of the NASD. Managers could direct give-ups or reciprocal business to these affiliates, as described supra at 4 .

The seriousness of the SEC about adopting Rule 10b-10 may be seen in Wall Street's reaction: "The Street thought the proposed rule had the looks of a lever intended to get the Exchange to move on a volume discount and to accede to the total abolition of give-ups." Loomis, Big Board, Big Volume, Big Trouble, 77 Fortune, May 1968, at 146, 221. If announcement of proposed Rule $10 \mathrm{~b}-10$ was meant as a bargaining lever, it was successful, see p. 830 infra. After the Exchange acceded to institution of a volume discount and abolition of give-ups, more drastic measures than the proposed SEC rulc, the Commission dropped plans to adopt 10b-10. 
Justice Department $t^{106}$ and the regional exchanges ${ }^{107}$ led the SEC to call for public hearings to explore commission rates and related problems. ${ }^{108}$

Throughout the summer of 1968, and sporadically since, the SEC has collected more than 6,000 pages of testimony on the commission rate structure. ${ }^{109}$ The testimony is weighted to reflect traditional SEC/NYSE bargaining concerns. Much testimony is by New York Stock Exchange officials. ${ }^{110}$ The SEC's presentation of witnesses is to a large extent aimed at exposing give-up procedures. ${ }^{111}$ Aside from a scattering of Wall Street mavericks, ${ }^{112}$ it was necessary for the Justice Department to get involved by presenting several economists to place in the record fundamental questioning of fixed commission rates. ${ }^{113}$ Use of private,

106. N.Y. Times, April 2, 1968, at 63, col. 5. The April 1, 1968 release of the ComMENTS OF THE U.S. DEPT. OF JUSTICE ON SEC RFLEASE No. 8239 , calling for ncgotiated commission rates on the Exchange, was considered "the worst blow of all" to Exchange hopes for maintaining the commission structure. Loomis, Big Board, Big Volume, Big Trouble, 77 Fortune, May 1968, at 146, 221. The Justice Department continucd to play a major role in setting the tone for the commission rate structure dispute with its version of the evidence presented in the 1968 SEC hearings in JusticE Departient, MEMoranduM ON The Fixed Minimum Commission Rate Structure (Jan. 17, 1969). That memorandun found no justification for fixed commission rates to serve any purposes of the Exchange Act. Opposition to fixed rates was continued through the change in Presidential adminis. tration in JUSTICE DEPARTMENT, CoMmenTs ON SEC RELEASE No. 8717 (Nov. 17, 1969) and Justice DePARTMENT, RESPONSE to SEC RELEASE 8791 (March 20, 1970).

107. Midwest Stock Exchange President Michael Tobin denounced the "bilateral negotiations" between SEC and Exchange, Tobin to SEC letter, March 29, 1968, SEC $10 \mathrm{~b}-10$ file \#57-319-1-2 at the SEC in Washington.

108. Securities Exchange Act Release No. 8324 (May 28, 1968).

109. SEC Rate Structure Investigation, supra note 74.

110. SEC Rate Structure Investigation, supra note 74, at 23-137, 2540.807, 5162.417.

111. SEC Rate Structure Investigation, supra note 74, at 1372.403, 1420.54, 1601.23, 1840-962, 1982-2050. With pointed questioning, the absurd justifications of give-ups were forced into the record. See the careful case being built up, through staff questioning, that the amount a broker is willing to give up has no relation to the cost of his exccution, testimony of officials of Pershing \& Co., at 144-207; and the case being built against it commission that covers ancillary services whether or not the customer uses them, testimony of TVilliam Donaldson of Donaldson, Lufkin \& Jenrette, at 737.851. In question. ing officials of Fidelity Management and Research $\mathrm{Co}_{\text {, }}$ at 1831.962, SEC Associate Director of the Division of Trading and Markets Eugene Rotberg pushed especially hard to make the Commission's point. After exposing a lie in Fidelity's testimony (at 1902), Rotberg led the witnesses through a description of give-ups made to forcign dealers to compensate them for "information." Rotberg sarcastically asked the question he knew the witness could not answer: "Would you please tell us what information you thought Bocttcher was getting from Hong Kong . . . Or Beirut, Lebanon?" at 1914. See similar questioning at $1782-90,1894-95,2030-34$.

112. SEC Rate Structure Investigation, supra note 74, testimony of M.A. Schapiro, at 3904-4003, and testimony of Donald Weeden, at 1461-508, 4004-61.

113. Lionel Kestenbaum of the Antitrust Division of the Justice Department opened the Department's presentation of six witnesses at the SEG hearings: "The Department believed that the Commission's evidentiary record on this issue would not be complete without expert analysis and comment on the basic policy question and the Exclange's economic argument." SEC Rate Structure Investigation, supra note 74, at 3527. To rebut the Exchange witnesses' arguments that fixed commission rates were necessary to tnaintain a strong, central marketplace, the Justice Department presented economists Paul Samucl. son, at $3530-6222$, William Baumol, at 3623-90, Flenry Wallich, at $3757-805$, and Harold Demsetz, at 3810-68. 
preliminary hearings allowed SEC officials to prepare their witnesses and to inform SEC cross-examiners ${ }^{114}$ so that the hearings could be used as an effective publicity device to push support for commission rate reform including implementation of a volume discount. ${ }^{115}$ Although the hearings proved inadequate as a record upon which to base a decision, as the SEC recognized by continuing private data collection, ${ }^{110}$ they made possible the expression of outside views and forced the Exchange publicly to defend its position.

Opening the commission rate structure to public scrutiny proved effective in late summer 1968 when the Exchange announced its intention to institute a volume discount and abolish give-ups. ${ }^{117}$ By letting the wind out of SEC sails, the Exchange seemed determined through minor reform to maintain the basic commission structure. ${ }^{118}$ The 1968 compromise was considered but an "interim solution," and the SEC and Exchange continued their private negotiations for the next three years. ${ }^{119}$ In early 1970, with several major brokerage houses filing for bankruptcy, ${ }^{120}$ completely private, secret negotiations between SEC and Exchange officials led to approval of a surcharge on small transactions less than two weeks after the Exchange requested it."121 Public hearings were held before renewal of the original 60-day "emergency

114. Securities Exchange Act Release No. 8328 (June 5, 1968) at 2, setting up procedures for the hearings, asks persons wishing to testify to file a description of the evidence to be presented to facilitate scheduling and "if necessary arranging preliminary conferences with and between interested participants."

115. The SEC was aware of most of the practices about which it presented witneses at the hearings; see Securities Exchange Act Release No. 8239 (Jan. 26, 1968). Pointcd questioning by SEC staff members, see note 111 supra, elicited answers which bolstered the Commission's criticism of give-ups.

116. N.Y. Times, Sept. 1, 1970, at 47 , col. 7.

117. N.Y. Times, June 28,1968 , at 57 , col. 8 . The cut in commission rates caused by the proposed volume discount amounted to an estimated $\$ 200$ million per jear. Loomis, They're Tearing Up Wall Street, 80 ForTuNE, Aug. 1, 1969, at 88, 158.

118. N.Y. Times, June 30, 1968, \& 3, at 1, col. 5; and Aug. 9, 1968, at 1, col. 1; 5 L. LOSS, SECURITIES REGULATION 3182 (Supp. 1969).

While the SEC was publicly pushing the Exchange through the hearings, it was also privately pressuring it through threats of 19(b) action unless the Exchange abolished give-ups and instituted a volume discount or negotiated rates for large trades, as described in Independent Broker-Dealers' Association v. SEC, Civil No. 22,252 (D.C. Cir. March 4, 1971), at 7-11.

119. Approval of the Exchange interim plan was given in a Cohen to Haack letter of Aug. 30, 1968. Securities Exchange Act. Release No. 8399 (Aug. 80, 1968).

120. See note 4 supra.

121. The approved surcharge of $\$ 15$ applied to orders of up to 1,000 shares, but was limited to not more than 50 per cent of the fixed commission. The letter from SEC Chairman Budge to Haack approving the surcharge included the stipulation: "The Commission ... expects the exchanges will tale all steps necessary to assure that full brokerage services to small investors are restored and that transiction size and other limitations on accounts of such investors which were imposed in the last year by a substantial portion of exchange membership will be removed." N.Y. Times, April 3, 1970, at 51 , col. 6 . 
financial relief," 122 but it required Congressional pressure to force the SEC to seek views other than those of the Exchange before granting the renewal. ${ }^{123}$

Not until the Exchange made its fourth rate proposal in July $1970^{124}$ did the SEC finally pass judgment on an entire rate revision. In October 1970 the SEC approved major portions of the proposal but called for substantial reductions in proposed small trade prices and negotiated rates for large transactions. ${ }^{125}$ The SEC and Exchange returned to the bargaining table to discuss these revisions, ${ }^{120}$ but the SEG finally lost patience and four months later requested large trade negotiated rates. ${ }^{127}$

122. Wall St. Journal, July 14,1970 , at 3, col. 2.

123. Congressman Moss of California, chairman of the House banking stubcommittce, wrote SEC Chairman Budge in June: "It is $\mathrm{my}$ sincere hope that the commission in the exercise of its responsibilities will act upon the application (for the surcharge cxtension) of the exchange only after the commission has held public hearings." Wall St. Joutnal, June 29, 1970, at 3, col. 2. Budge had earlier stated that no hearings were contemplited for the surcharge extension alone. Moss threatened Congressional hearings if the SEC did not develop a public record. Wall St. Journal, July 3, 1970, at 3, col. 4. The SEC received more than 3,000 letters complaining about the surcharge. Welles, Can the New York Stock Exchange Survive? INSTITUTIONAL INVESTOR, June, 1970, at 76.

124. Wall St. Journal, July 1, 1970, at 14, col. 1; June 30, 1970, at 3, col. 1. The July proposal was preceded by the third proposal in January, based on a study of costs and profits of member firms done for the Exchange by National Economic Research Associates. The plan called for cuts of up to 37.5 per cent in commissions on certain large transactions. N.Y. Times, Feb. 14, 1970, at 1, col. 2; Feb. 16, at 53, col. 8.

125. Wall St. Journal, Oct. 26, 1970, at 30, col. 1. The SEC approval came in the form of a Budge to Haack letter of Oct. 22, 1970. CuRRENT CCH FED. SEC. L. REP. \ 77, 919 (1970). The SEC called for rollbacks as great as 25 per cent in the increased rates for 100 to 400 share transactions, and stated that fixed minimum commissions for portions of stock orders over $\$ 100,000$ were neither "necessary or appropriate." A preliminary estimate was that the SEG suggestions would lop off $\$ 100$ million of the $\$ 550$ million in increased commissions expected from the Exchange proposal.

126. Chairman of the Exchange Board of Governors Bernard Lasker and Vice Chairman Ralph DeNunzio met with SEC officials. However, Exchange President Haack did not accompany them. Although Haack claimed other commitments, his disagrcement with many governors of the Exchange over the commission rate structure appeared to be an equally plausible explanation for his absence. Wall St. Journal, Nov. 23, 1970, at 2, col. 3 . During the previous week, Haack had stunned Wall Street by calling for an end to all fixed commission rates across the board, although the SEC had asked negotiatcd rates only on some large orders in its Oct. 22 letter. Criticizing the SEC for failing to cnforce an end to give-ups and reciprocal means of commission splitting, as had been called for in the 1968 interim proposal, Haack said such practices continued, forcing many trades into the third market and onto regional exchanges. He said these practices threatencd the Big Board. N.Y. Times, Nov. 18, 1970, at 1, col. 2; Wall St. Journal, Nov. 18, 1970, at 3, col. I. Haack's speech drew criticism from many Exchange members and began rumors that he would be fired. N.Y. Times, Nov. $22,1970, \S 3$, at 1 , col. 2.

127. The request came in a February 10, 1971 letter to Exchange President Haack from SEC Commissioner Richard Smith. Current CCH FEd. SEc. L. REP. ף 77, 955 (1971). Nothing was said in the letter about the earlier objections to proposed rate increases in the 100 to 400 share range, and a compromise from the October position was involved: negotiated rates were required only for transactions over $\$ 500,000$, not $\$ 100,000$.

Whether the October 1970 letter was an official 19(b) request for an Exchange rule change poses an interesting question. Section $19(\mathrm{~b})$ authority is never mentioned in the letter, and it is written in terms of whether the SEC would approve of a future rate change, not a request for an alteration in the existing rate structure. Yet, the letter clcarly had its source in 19(b)(9) SEC oversight of the setting of a "reasonable rate of commission." The February, 1971, letter, however, talks of the need for "immediate action to implement" 
SEC treatment of the commission rate issue has been a departure from informal bargaining practices; throughout the six-year period, views of both the Exchange and SEC have been public, and views of other parties have been placed in the public record. There has, however, still been substantial private negotiation; and the first SEC approval of the surcharge was accomplished in the traditional informal bargaining fashion. Articulation of the necessity for fixed commission rates on small trades and negotiated rates on large trades or of a reasonableness standard is noticeably lacking in SEC approval of the most recent Exchange rate schedule. ${ }^{128}$ The SEC has adopted on this regulatory issue some of the instruments for structuring discretion; but in important respects, the informal pattern has remained unchanged.

\section{(4) Other Rule Changes}

In the three described SEC/NYSE conflicts, although there was much informal bargaining, final resolution of the issue was made public. Much day-to-day regulation of the Exchange, however, is completely private. The Exchange is required to give the SEC three weels notice before any Exchange-initiated rule change becomes effective. ${ }^{120}$ In most instances, neither the Exchange nor the SEC announce submission of such rule changes. The SEC may object in part, or in whole, to the proposed change. It is often possible for the SEC and Exchange to bargain out resolution of disagreement; such bargaining may be over the telephone, and no written record will be made. No one but agency officials may know what considerations went into the finally agreedupon rule change. ${ }^{130}$ Many such rule changes may be technical and of

negotiated rates. Although also not mentioning 19(b), the letter does call for a change in existing Exchange practices. If the April deadline had not been complied with, it would seem possible for the SEC to consider the letter as a 19(b) order. Thus, after "opportunity for hearings," the SEC could formulate "rules and regulations to alter or supplement the rules of such exchange." Of course, extensive hearings on the commission structure have already been held, but 19(b) is procedurally structured for hearings after the Exchange has refused compliance with an SEC request. See Securities and Exchange Act of 1934 \& $19(\mathrm{~b})$, 15 U.S.C. § 78s (1964). The SEC did not consider the April letter a 19 (b) order, but private litigants could challenge that interpretation.

128. The SEC letter of Oct. 22, 1970 on the Exchange's July rate proposal contains no discussion of the policy issues involved in approving a "reasonable" rate proposal. Cusnest CCH FED. SEC. L. REP. I 77,919 (1970).

129. Securities Exchange Act Releases Nos. 7218 (Jan. 9, 1964) and 7253 (Niarch 3. (1964). Since 1962 the Exchange had been following a policy of discussing rule changes with the SEC staff before submission of them to the Board of Governors, instead of doing so only occasionally as it had done previously. $5 \mathrm{~L}$. Loss, SEcurrties REcuLATros 3151 (Supp. 1969). Although the Exchange did not challenge in 1964 promulgation of Rule 172.8 requiring three weeks notice, it reserved the right to challenge it at a dater time, becuse it claimed the SEC had no power directly to approve or disapprove of an Exchange rule change.

130. Securtites and Exchange Comarission, 35Th ANwuac Report 70.71 (1989) mentions 
little consequence; but the decision whether or not to open consideration of these changes to the public is completely discretionary with the SEG.

\section{The Issue of Informality}

\section{A. Pros and Cons}

Description of the SEC/NYSE relationship emphasizes three dangers of informal regulation: ${ }^{131}$

(1) Lack of openness to public scrutiny is most significant at the SEC during the period before decisions are made. If an agency gives public notice of an issue with which it is concerned or holds public hearings before it makes its decision, interested parties can provide information and viewpoints with which they feel the agency may not be acquainted. The SEC practice of announcing decisions already bargained out with the Exchange, subject to comments interested parties file, may elicit additional information; but the weight given these comments will be of lesser value when agency and Exchange have already become committed to a decision. In addition, because the Exchange is often not required publicly to announce its position, the public is deprived of the major information and viewpoints on which the Commission bases decisions.

Current bargaining ignores the wide diversity of the securities industry. Although the New York Exchange may be the most important securities market, its members are not the only persons interested in, and financially affected by, SEC decisions on Exchange practices, ${ }^{132}$ New York members are not always in complete agreement with Exchange policies. ${ }^{133}$ Dissident New York members, regional exchanges, over-the-counter and third market dealers are excluded from the contact with the regulatory process which the Exchange enjoys. Beyond industry interests, the SEC is mandated to consider the public

96 exchange-initiated rule changes submitted to the SEC, but describes only a few of them and discusses only one.

131. These three dangers are related specifically to Davis" instruments for structuring discretion at p. 839 infra. Davis writes of unstructured discretion: "I think the greatest and most frequent injustice occurs at the discretion end of the scale, where rulcs and principles provide little or no guidance, where emotions of deciding officers may alfect what they do, where the imperfections of human nature are often reflected in the cloices made." K. DAvis, supra note 10, at v.

132. Ralph Saul, President of the American Exchange and former SEG staff member, has recently called for "new organizations or arrangements" for regulating the securities industry, because, for one basic reason, "major elements" of the industry are not now sufficiently represented. Wall St. Journal, Nov. 16, 1970, at 3, col. 1.

133. See pp. 821, 827-29 supra. 
interest. The investing public may often have a different perspective from the Exchange. Although there is no designated representative of the public, except to the extent that is the role assumed by the SEC itself, various organizations represent investors, and their spokesmen have appeared at hearings. ${ }^{134}$ If an issue is significant and access to the Commission is available, more spokesmen may appear.

(2) Lack of policy articulation is possible with the informal bargaining process because the agency does not write an opinion based on a public record. Opinions, if they are to be given credence, must take into account opposing viewpoints and conflicting information in the record. Flaws in the rationale of a decision often become apparent only when it is put in writing. Without opinions based on a record, SEC officials are free to fashion decisions solely on personal principles and motivations; consistency can easily be avoided. Congress and the courts obviously depend on articulation of policy to scrutinize agency use of its discretion and faithfulness to legislative intent. Although agency actions can be observed without articulated policy, written opinions clarify and call attention to issues, a significant factor in an informal bargaining environment with a lack of openness.

(3) Dependence on the policy views and personalities of an agency's officers is a factor in all administrative decision-making, but it is exacerbated by informal bargaining. No matter how knowledgeable and public-spirited the SEC is, close relationships which develop between Commission and Exchange officials inevitably limit the agency's perspective. ${ }^{135}$ The essence of the bargaining process is compromise;

134. Hans Reinisch, founder of the National Shareholders Association, testified at the summer 1970 Securities Investor Protection Hearings on H.R. 1330S, H.R. 17585, H.R. 18081, H.R. 18109, and H.R. 18458 Before the Subcomm. on Commerce and Finance of the House Comm. on Interstate and Foreign Commerce, 91st Cong., 2d Sess. 239-52 (1970).

135. As is typical with all the Washington regulatory agencies, the SEC deals daily with industry officials who are former SEC stalf members and commissioners. Anerican Exchange President Ralph Saul led the 10-man SEC committec investigating the Amex after its early 1960's scandals. Businessmen in the Neus: Ralph Saul of the American Exchange, 74 ForTune, Oct. 1966, at 47. In private practice in Washington are former SEC chairmen Manuel Cohen and Edward Gadsby and Exchange Act co-author Thomas Corcoran. Zalaznick, The Small TWorld of Big Washington Lawyers, 80 FonTuNe, Sept. 1969, at 121. Tithin months after leaving the SEC, Cohen was sccking cxemption from SEC requirements for a new computerized securities system. Loomis, They're Tearing $U_{p}$ Wall Street, 80 Fortune, Aug. 1969, at 88. The Exchange's first ofter of its presidenc; after Funston's retirement went to former SEC Chairman Donald Cook. When he declined, SEC Chairman Cohen's golfing partner, Robert Haack, was chosen. Loomis, Big Board, Big Volume, Big Trouble, 77 Fortune, Alay 1968, at 146, 148-49.

The quality of SEC officials has been very significant in determining agency policy. When the SEC has not been an aggressive regulator, it has been possible to place blame on the character of the officials holding the reins. Explanation of the pause in the drive to implement Special Study suggestions during 1965 was attributed largely to the absence of one man, the aggressive Chairman Cohen, for four months because of illness. N.Y. Times, Jan. 17, 1966, at 107, col. 1. Blame for the allegedly "near-paralyzed" state of the agency in 
men constantly involved in that process begin to share viewpoints with those on the other side of the table, ${ }^{136}$ and they are almost always Exchange officials. The opportunity for trade-offs between Commission and Exchange can easily submerge the public interest in bargaining considerations.

These three dangers combine to place vast discretion in the SEC. Guided only by principles such as "just and adequate to insure fair dealing" and "for the protection of investors," 137 the SEC has broad, undefined statutory goals, susceptible to a wide range of interpretation. The SEC was granted broad discretion in 1934 because Congress felt itself too unknowledgeable about exchange practices to give more guidance. ${ }^{138}$ Attention then was focused on gross abuses of trading privileges and large-scale manipulations of stock prices. ${ }^{130}$ Congress wanted such practices ended, but it left to the SEC development of expertise to determine the best methods for achieving these goals.140 Lack of legislative guidelines is of even greater significance in relation to a wide spectrum of current regulatory questions which were not even considered by Congress in 1934. Major policy questions on the com.

spring, 1970 was placed on the lack of dynamism of Chairman Budge. As one former staff member was quoted, "The commission with all its powers, has limited power. It takcs dynamic leadership to make the commission important in the securities markets. Budgc hasn't provided that leadership." N.Y. Times, June 1, 1970, at 54, col. 1. On the other hand, the SEC's early success just after passage of the Exchange Act has been attributed to "some of the most phenomenal talent that the New Deal ever crowded into any regulatory agency." DEBEDTs, supra note 3 , at vii.

136. Former SEC Chairman Cary outlines the four types of influences on SEC officials which may lead to overly favorable attitudes toward the industry: (1) many commissioners are, at least when appointed, captives of the industry; (2) "hardening of the arterieslack of initiative in fostering new programs;" (3) "the fact that the parties arc dealing with the industry day to day and begin to appreciate their problems without taking due account of the public interest;" and (4) "an actual lack of personal independence on the part of commissioners." W. CARY, supra note 20 , at 67.

S. RobBins, supra note 39, at 122, stresses two other determinants of the regulators" attitudes: "Association with the field may lead SEC commissioners to develop a confidence in its activities and friendliness towards its participants that make difficult the firmness sometimes demanded of an overseer."

Cary backhandedly notes the limitation on the SEC caused by the close relationship with the industry in discussing the desirability of having the Special Study done by men from outside the SEC: "It was better that if a firm and hardened position were to bc taken, it be taken by an outside group, for otherwise it would be impossible to deal witl the industry." W. CARY, supra, at 76.

137. Securities and Exchange Act of 1934 \& 19(b), 15 U.S.C. § 78s(b) (1964).

138. See testimony of J. M. Landis, at that time commissioner of the FTC and a drafter of the Exchange Act, Exchange Act Hearings, supra note 20, at 20-23.

139. Thomas G. Corcoran, one of the drafters of the Exchange Act, listed the five problems the act was concerned with: (1) credit control; (2) market manipulation; (3) pro. tecting outsiders from insiders; (4) ending speculative abuses; and (5) deciding what agency should do the regulating; in his testimony at the Exchange Act Hearings, supra note 20, at $85-86$.

140. In at least two instances the original draft of the Exchange Act called for specific guidelines for regulations, which were dropped from the final Act to give the SEC dis. cretion to fashion remedies. See p. 819 and note 66 supra. 
petitive structure of the securities industry have been intrinsic to Commission decisions during the past ten years, ${ }^{141}$ but a search of the legislative history offers no guidance to Congressional intent in these areas. ${ }^{142}$ Procedural formalities are of special significance with such broad substantive guidelines. The SEC has the responsibility of filling in the broad goals with more specific policies. It is thus important that it be open to the views of all interested parties, and that it articulate the more specific policies which form its regulatory decisions. In the absence of the procedural formalities, the agency is susceptible to myopia and to arbitrariness, because it is free not only from the check of statutory guidelines, but also the checks of exposure to other interested parties and of the necessity of publicly articulating what it is attempting to accomplish.

Criticism of the informal regulatory pattern, though, must take note of its potential for expeditiously resolving regulatory issues. Four advantages of the informal process-speed, mutual confidence, inexpensiveness and flexible power-deserve scrutiny.

(I) Informal regulation can be rapid. Many SEG suggestions for rule changes can be handled in several days. Delay would be inevitable with solicitation of public comments or hearings. Six years plus of wrangling over commission rate reform raises doubts on the desirability of opening regulatory issues to the public. Hearings use up much SEC time, and with the small size of the SEC staff overseeing Exchange practices, use of more formal procedures might immobilize aggressive regulation. ${ }^{143}$

Necessity for rapid regulatory actions, however, should not be given undue emphasis. If changes are minor, great disapproval from outside parties is unlikely; solicitation of written comments alone, without public hearings, should suffice to serve notice-giving and informationgathering functions. If changes are more important, it is undesirable

141. Major policy questions which the SEC has avoided answering, but which have been intrinsic to decision-making in recent years, include: What are "reasonable" rates of commission? Should large institutional investors subsidize small investors as they have been doing under the fixed commission rate structure? What number of firms in the investment industry is optimal? Is it necessary that the industry have a strong central securities market place, as the New York Stock Exchange has been? What is the role of regional exchanges?

142. Baxter, NYSE Fixed Commission Rates: A Private Cartel Goes Public, 22 STAN. L. REv. 675, 684-85 (1970) finds, "one fact that emerges clearly from the two securities statutes and their history is that the attention of Congress in 1934 was focused on problems of dishonesty, manipulation, and solvency, and that no coherent congressional purpose was articulated concerning the problems of intra-industry competitive structure."

143. The SPECLAL STUDY, supra note 8, pt. 4, at 719.20, notes the inadequate size of the staff at the Division of Trading and Markets overseeing exchange self-regulation. Only about ten attorneys are involved in oversight of all securities exchanges. 
that they be approved without benefit of views other than the Exchange's. ${ }^{144}$ In some regulatory activity, speed may be important in meeting emergency conditions; ${ }^{145}$ but in reforming general Exchange practices, some of which the SEC left unchallenged for years, ${ }^{140}$ speed is not of such value. Should it become necessary, provision for temporary approval, subject to further examination with the help of outside comments, could be granted by the Commission. ${ }^{\mathbf{1 4 7}}$

(2) The confidence engendered in the informal bargaining process encourages candor in discussion and generous sharing of information during behind-the-scenes negotiations. The Exchange can be frank about failings of its self-regulatory mechanism without fear of public indignation or repercussions on the stock market. The SEC is aided in

144. See note 156 infra.

145. Speed is important for suspension of the trading in a particular stock to prevent further price dislocations under Securities and Exchange Act of 1934 \$ 19 (a)(4), 15 U.S.C. $\S 78 \mathrm{~s}$ (a)(4) (1964); see Comment, Summary and Successive Suspension of Trading Under the Exchange Act of 1934, 18 CaTH. U. L. REv. 57 (1968).

146. See p. 820 and note 66 supra.

147. If the SEC initiates consideration of reform in Exchange rules or practices, there is no need for temporary orders. As in the floor trading dispute, the SEC could lave, although it did not, presented its preliminary views and asked for comments before it reached a conclusion and requested the Exchange to amend its rules. The Exchange would be expected to make its views known publicly, just as other interested parties would. If the Exchange did not wish to comply with the first SEG request, made after the Commission had digested all views presented, then the hearings and order provisions of $19(\mathrm{~b})$ could be used.

However, if the Exchange rule modification is initiated by the Big Board, as many changes have been, the procedures set up by 19 (b) are not so amenable to public participation. The Maloney Act calls for SEC approval of all rule changes made by overthe-counter associations, Securities and Exchange Act of 1934 \& 15A(i), 15 U.S.C. \& 780.9(j) (1964); but there is no such requirement for exchange oversight. Section 19(b) does not require SEC approval of Exchange rule amendments. However, this Note has disctisscl SEC approval of Exchange-initiated rule changes as if that were the case, becalise the informal pattern has developed a procedure by which the SEC contacts the Exchange after it receives the three week notice of rule changes required under Rule $17 \mathrm{a}-8$, sce note 129 supra. By thus contacting the Exchange, the SEC either gives its unofficial approval or disapproval, in part or in whole, of the change. Either way, the Exchange and Commission privately bargain out their differences, although in cases of major rule changes such as the Exchange commission rate proposals, the issue may become public.

It has been suggested that 19(b) should be amended to parallel the Maloncy Act's section $15 A(j)$, thus requiring SEC approval of all Exchange rule changes. Jennings, Self-Regulation in the Securities Industry: The Role of the Securities and Excltange Commission, 29 LAw \& CONTEMP. ProB. 663, 689 (1964). But such amendment would be unnecessary for implementation of the public notice suggestion made here. Although the SEG need not pass judgment on proposed Exchange-initiated rule changes, as soon as the change is made, 19(b) allows the Commission to "alter or supplement" the rule. "Thic SEC could follow a standard procedure of asking comments on all Exchange-initiated rule changes. If the SEC itself, or the SEC as influenced by the comments received, fccls the Exchange rule change is undesirable or inadequate, it could then start the 19(b) machinery, after the rule change has been implemented. This procedure would be cumbersome. it would be simplified were the SEC required to approve all Exchange rule changes in the first place. But, barring legislative amendment in the near future, the SEC could still provide for the public notice function within the present statute. Any cumbersomencss caused by Exchange implementation of a rule change closely followed by an SEC call for further change is outweighed by the desirability of ending the private, secret negotiations which now constitute SEC approval of Exchange-initiated changes. 
developing expertise and matching the Exchange in its familiarity with the issues.

The advantages of mutual confidence, however, are not as significant as at first glance. Should confidence break down, the SEC can subpoena information if it must. ${ }^{148}$ There may be useful unwritten accounts of dealings at the Exchange about which the SEC would not be apprised routinely under a more formalized regulatory pattern; ${ }^{149}$ but to the extent the Exchange now keeps the SEC informed to create an atmosphere in Washington favorable to Exchange practices, information will continue to be supplied. If the SEC is now privy to information embarrassing to the Exchange, cover-ups are not in the public interest. The SEC was not set up to be, and should not be, a shield for Exchange practices. Repercussions on the stock market should not be severe unless the Exchange is seriously neglecting its self-regulatory duties. An open, public SEC/NYSE relationship itself should act as a means of allaying some of the fears which cause repercussions because of investor suspicions that the Exchange "private club" mentality is not reduced when the SEC and Exchange privately bargain compromises.

(3) Both the speed and mutual confidence advantages assume limitations on SEG staff time. Public notice, hearings and use of subpoenas might burden the SEC staff and increase the cost of SEC operations. But staff limitations should not be an excuse for not demanding the appropriations needed for proper surveillance of the Exchange. Generous appropriations for the Special Study indicate measures Congress has taken when a need has been shown. ${ }^{150}$

(4) Under the present regulatory pattern, the SEC wields great flexible power, which might be hampered by procedural requirements. The Exchange wishes to keep the existing bargaining modus operandi; thus by threatening formal section 11 or $19(\mathrm{~b})$ proceedings or public hearings, the SEG has strong leverage tools, which it has used.101 If formal proceedings are always held, the bargaining threat is removed. The Commission is now free to choose issues it feels are most important, and compromise on other issues with the Exchange, to achieve what it

148. Securities and Exchange Act of 1934 \&21(b), 15 U.S.C. \& 78u(b) (1964).

149. An example of "inside" Exchange dealings, knowledge of which is hclpful to SEC administrators, is the operation of the Crisis Committee of the Exclange set up within the past year to stave off bankruptcy of major brokerage firms. N.Y. Times, Jan. 24, 1971, § 3, at 1 , col. 2.

150. Congress appropriated almost \$1 million for the Special Study, allowing the SEC to recruit an extra staff of 65 persons to investigate the industry. SPECiNL STiDY, supra note 8, pt. I, at 1 n.I, 7 .

151. See pp. 819-30 supra. 
considers the most important regulatory goals. ${ }^{162}$ The Commission can begin discussion of an issue with the Exchange, and, should reform prove fruitless or unwise, abandon the campaign without raising cries of "sell out."

Existence of flexible power, however, is an advantage of informal bargaining only to the extent such power would be lost with more formalized proceedings. SEC hearings on commission rates prompted the Exchange to reform without a public fight despite the reality that no matter what it did hearings would be held. ${ }^{163}$ Section 11 and 19(b) authority need be no less fearsome in their formal use than in their threatened use. Formalizing procedures could lead to a more adversarial regulatory environment; having lost the advantages of informality, the Exchange may, rather than compromising at an early stage, challenge the SEC openly and fight to the end, including resort to judicial revierw. But, if the SEC is already doing a conscientious, effective job, judicial reversals of decisions should be unlikely; the SEC's flexible power should not be impaired. If the SEC is presently regulating to the detriment of the investing public, it is undesirable that there not be judicial disapproval.

Flexible use of SEG authority also may be detrimental to statutory goals. Use of compromises and of sham issues to push reform raises the specter of the Commission not seeking the best solution to each regulatory issue. The SEC was given wide authority not to make improper compromise possible, but to provide oversight of many Exchange activities.

\section{B. Recommendations}

The informal bargaining process is an inadequate means of regulating today's securities industry. The advantages claimed are less persuasive than the dangers inherent in continuation of the informal bargaining pattern, especially when the SEC must now not only eliminate unfair practices on the New York Exchange as originally mandated in 1934, but also consider broad policy questions on the competitive structure of the securities industry in a time of flux. ${ }^{154}$

152. In the summer of 1963, a year before promulgation of Rule 11a.1 on floor trading, the Exchange was expected to give in to SEC suggestions on floor trading reform in orcler to strengthen its stand resisting alteration of rules governing specialists and odd lot dealers. N.Y. Times, March 22, 1964, § 3, at 1, Col. 5 .

153. See p. 829 supra.

154. See, e.g., Other People's Money, NEw REPuBdic, Jan. 23, 1971, at 9; The Market: Time for a New Broom, NEwswEEK, Nov. 30, 1970, at 71. Unhappiness with the state of the securities markets and their regulation has led to calls for congressional hearings in 
Formalization of procedures in three ways to improve the regulatory pattern follows from the foregoing discussion: (1) the SEC should give notice to and solicit comment from the public on any issue of Exchange regulation under consideration before determination of a solution; ${ }^{16 J}$ (2) public hearings should be held on issues of major importance or over which there is much controversy; ${ }^{100}$ (3) the SEC should write an opinion articulating its findings and reasons in connection with any Exchange reforms it approves. Implementation of these three suggestions would greatly improve the SEC's structuring of its discretion in terms of Professor Davis' seven criteria. Giving notice and holding hearings is essential to fair non-judicial procedures which give a voice to all interested parties. These procedures make possible the compilation of a record from which the SEC can derive open findings. Open findings will be evidenced in the written opinion of the Commission along with an open statement of policy, rules, reasons and precedents.

If the SEG does not voluntarily formalize its regulatory pattern, judicial challenges to its involvement in Exchange activities are likely. Courts will face two major questions in scrutinizing SEC actions: (1) Is there jurisdiction to review informal agency actions? and (2) TWas SEC procedure adequate? The questions were faced in the context of an SEG 19(b) action for the first time in the recent case of Independent Broker-Dealers' Trade Association v. SEC. ${ }^{157}$ The D.C. Circuit had opened up judicial scrutiny of informal agency actions last year by declaring, "we see no substantial reason why the absence of formal adjudicatory hearings in the regulatory scheme should render Commission decisions, however capricious or erroneous, utterly immune to direct judicial review or redress."108 This principle was applied in

both the House, N.Y. Times, Dec. 2, 1970, at 1, col. 5, and Senate, N.Y. Times, March 9, 1971 , at 47 , col. 6 .

19(b).

155. See note 147 supra for a discussion of the vorkings of the recommendation under

156. Distinguishing between agency actions which require only notice and written comments and those which require public hearings could best be handled by announced SEC guidelines. Clearly the commission rate structure issue is important cnough to require hearings, and technical changes in Exchange rules approved by the SECC could sufficiently be handled through written comments; drawing a line within those two extremes is difficult. Considerations which should be involved in the line-draving include whether the change affects parties other than Exchange members, whether it involies sanctioning of anticompetitive Exchange activities, and the breadth and depth of the concern of other parties with the change. Most significant is the need for openly announced Commission guidelines for the agency's discretionary decision on whether or not to hold hearings. See K. DAvis, supra note 10, at 54-57.

157. 39 U.S.L.W. 2506 (D.C. Cir. March 4, 1971).

158. Medical Committee for Human Rights v. SEC, 432 F.2d 059 (D.C. Cir. 1970), cert. granted, 39 U.S.L.W. 3413 (U.S. Miarch 22, 1971). The court found in the Exchange Act, SEC regulations and case precedents authority to review the SEC's decision not to object 
Independent Broker-Dealers in the court's review of SEC involvement in the Exchange's abolition of give-ups in 1968.150 The court recognized that SEC threats of 19(b) action to push Exchange reform are often effective without the necessity for 19(b)'s "opportunity for notice and hearing." 160 Thus if the Exchange complies voluntarily with a SEC suggestion, there may be no notice or hearings to other interested parties. The court relied in finding jurisdiction to review not on the mention of 19(b) authority in SEC letters to the Exchange, but on SEC pressure on the Exchange which "amounts to more than a mere invitation to voluntary compliance, and carries .... an element of undue influence and sufficient dangers of intrusion into matters beyond the scope of the Commission's power." ${ }^{101}$ The court realized that although procedures were informal, their effects in changing Exchange practices were the same as if formal proceedings with notice and hearings had been held. The Commission's action became final when the Exchange accepted the suggestion to end give-ups. Other interested parties had no adequate remedy except judicial review. ${ }^{102}$ Thus, whenever the SEC is closely involved with an Exchange rule modification, as it was in all three SEC/NYSE disputes described here, the court will be able to find jurisdiction to review the Commission's actions.

In reviewing the adequacy of the procedures by which the SEC pushed the Exchange to abolish give-ups, the court demanded "elementary fairness" including "reasonable opportunity . . . for submission of views by those materially affected." 103 Once the court had equated

if Dow Chemical Co. did not include the Medical Committee's proposal in its proxy statement, although the Commission's action was made completely through informul communication between Dow, the Medical Committee and itself.

159. Independent Broker-Dealers' Association v. SEC, 39 U.S.L.W. 2506 (D.C. Cir. March 4, 1971). See discussion of this regulatory move at pp. 827.829 stipra.

160. See the discussion of the use of $19(\mathrm{~b})$ as a threat to accomplish Exchange com. pliance at pp. 825-26 supra.

161. Independent Broker-Dealer's Association v. SEC, Civil No. 22,252 (D.C. Cir. March 4, 1971), at 17. The court relies on the Administrative Procedure Act \& 10(b), 5 U.S.C. \$ 704 (1964), making reviewable "final agency action for which there is no other adcruate remedy in a court." It notes the danger, as emphasized in Moss v. CAB, 430 F.2d 891 (D.C., Cir. 1970), that government actions will be concealed as purely private Exchange actions in order to preclude judicial review. Independent Broker-Dealers Association, supra at 16.17. The court notes, "The possibility that the Exchange might have taken the same action on its own provides no basis for declining jurisdiction over pressures by the Commission that may wrongfully influence and intrude on its decision-making;" sitpra at 19.

162. In 1954 the securities industry was very concerned that $19(\mathrm{~b})$ actions be open to judicial review. At the time the SEC calmed the industry by stating that there was no need for all $19(\mathrm{~b})$ actions to be made by formal orders in order to be reviewable in light of Columbia Broadcasting System v. United States, 316 U.S. 407, 416 (1942) and Philadelphia Co. v. SEC, 164 F.2d 889 (D.C. Cir. 1947), cert. denied 333 U.S. 828, See 2 L. Loss, SEcurituts REGULATION 1183 (2d ed. 1965).

163. Independent Broker-Dealers' Association v. SEC, Givil No. 22,252 (D.C. Cir. March 4, 1971), at 21. 
the substantive effects of informal pressure on the Exchange with what would occur had the SEG used more formal proceedings to cause Exchange rules to be changed, it followed logically that elementary fairness to other parties affected by the Exchange rule change be required. On the give-up issue, the SEC had made public long in advance of its approval of the Exchange's abolition of them its concern with the issue; public comment had been solicited; hearings had been held. ${ }^{10}$ Thus the court had little difficulty finding the Independent Broker-Dealers had an opportunity to express their views to the agency. ${ }^{105}$

The court, however, did not require the SEC to articulate policy and findings on the give-up issue: "the Commission need not make an ultimate finding in order to lodge a preliminary request with the Exchange, even if the request is accompanied by certain pressures toward compliance."168 The court allowed give-ups to be abolished at SEC urging "even though there has been no agency finding as to its advisability." In not demanding articulation, the court departed from its realization that the effects of informal pressures are the same as those of formal proceedings in causing substantive reform. It would seem logically to follow that if an agency must rationalize its decisions after formal proceedings, it should also rationalize its findings and policies when through informal actions it causes the same substantive changes. The failure of the court to extend its realization of the equivalency between informal and formal procedures, on which it predicated its findings of jurisdiction to review and need for elementary fairness, to a demand for articulation of policy provides inadequate judicial review. Notice and hearings are of little value to aggrieved parties if the agency is allowed to ignore the information presented. Articulation of findings and policies is a procedure which forces agency attention to these opposing views. ${ }^{168}$

The D.C. Circuit's decision in Independent Broker-Dealers marks a beginning of judicial recognition of the broad authority wielded by the SEC through informal procedures. ${ }^{109}$ The court has recognized some

164. See pp. 827-31 supra.

165. Independent Broker-Dealers' Association v. SEC, Civil No. 22,252 (D.C. Cir. March 4, 1971), at 22-23.

166. Id. at 24 .

167. Id.

168. In Medical Committee for Human Rights v. SEC, 432 F.2d 659, 682 (D.C. Cir. 1970), cert. granted, 39 U.S.L.W. 3413 (U.S. March 22, 1971), after finding jurisdiction to review the informal proxy actions of the Commission, the court specifically remanded for articulation of the Commission's policy and findings, "so that the basis for [its] decision [may] appear clearly on the record, not in conclusory terms but in sufficient detail to permit prompt and effective review."

169. Review of the Exchange's abolition of give-ups at the urging of the SEC provided 
structuring of the broad discretion involved in this regulatory pattern is necessary. The task now is to devise a broad, flexible framework, perhaps similar to Professor Davis' seven instruments, which can be used to evaluate appropriateness of agency procedures and to require agencies to give notice, hold hearings and articulate policies when failure to follow these procedures will deprive interested parties of elementary fairness. The evidence presented in this Note substantiates the argument that the requirement of some procedural formalities at the SEC in its regulation of the New York Stock Exchange will alleviate some of the disadvantages of the current informal bargaining process without seriously impairing the SEC's role as an effective regulator.

\section{Conclusion}

Although the procedural recommendations should reduce the dangers of lack of openness, lack of policy articulation and over-dependence on the particular personalities of SEC officials, their limited effective. ness should also be recognized. Openness gives interested parties the opportunity to be heard, but there is no guarantee the Commission will pay attention. Written opinions based on a public record force some atten. tion to conflicting data, but the necessity for the agency may become the writing of competent opinions which account for the data and still achieve the result that would have been achieved without it. ${ }^{170}$ Simi. larly, articulation of policy can become but a requirement of wellwritten opinions which cleverly articulate the policy necessary to justify a result.171 Over-dependence on particular SEG personnel will not be

a major break-through for finding judisdiction to review SEC informal actions; but the court was not pressed to confront the more informal bargaining process which hats characterized SEC actions on reforms other than the commission tate structure. Seet pp. 825-30 supra. By holding public hearings and soliciting outside comments, the SEC had deviated from its more usual bargaining pattern on this issue.

An argument that the decision in Independent Broker Dealers expands the scope of civil liability of Exchange member firms for violations of Exchange rules is made in $\mathrm{N}$. Wolfson and T. Russo, The Stock Exchange Member: Liability for Violation of Stoct: Exchange Rules, 58 CALIF. L. REv. 1120 (1970). If Exchange rules are to be given this expanded impact, the need for public scrutiny of the SEC process of approval of the rules is of even greater significance than in the past.

170. Although admitting that getting all the information on the table is a uscful first step, Marx, Administrative Regulation in Comparative Perspective, 26 LAw \& CoNTEMP. PROB. 307, 321 (1961) emphasizes the substantive reality behind the procedural formallty: "Notices of intent and provision for hearing are auxiliary to arriving at a finding. It is the finding that is indispensable."

171. The January, 1970, Exchange rate proposal was bascd on a cost analysis of member firms. If the Commission decided to base a reasonableness standard upon such data, articulation of policy would seem simplified and unsusceptible to manipulation, but as an "economist points out ... costs are just as susceptible to tilting as rates and ... the Exchange's analysis presents numerous opportunities for adroit data massaging. Various 
limited if the personnel are intelligent administrators capable of using data advanced to mold the policy articulated to the result desired. Substantive improvements in SEC regulation need not necessarily follow from procedural advances.

The limited usefulness of procedural devices to improve SEC regulation makes it desirable that substantive SEC policies also receive scrutiny. When the Exchange Act was approved 37 years ago, Congress was ignorant about many Exchange practices and it did not consider the problems of the competitive structure of the securities industry. The Exchange Act contains only the broadest substantive guidelines for SEC promotion of open and honest markets and no guidelines for SEC participation in the structuring of competition in the industry. ${ }^{172}$ The securities industry is presently operating in the wake of major disturbances of and challenges to Exchange practices. The "scandal syndrome" has once again become effectual, in part because of Exchange volume fluctuations and consequent paperwork and capital problems, ${ }^{173}$ but more significantly because communication and automation advances have placed in doubt the necessity of continued protection of the New York Stock Exchange as the nation's strong central securities marketplace. ${ }^{174} \mathrm{It}$ is appropriate that Congress re-examine the desirability of grants of vast discretion to the SEC with few or no legislative guidelines. Congressional review would be especially helpful in guiding discretion in the conflict between the SEC's sanctioning of Exchange anticompetitive practices and the policies underlying the Sherman Act.

Congressional consideration of conflicts between SEC policies and the antitrust acts should concentrate in part on the appropriateness of

"public interest' objectives could be mixed in." Welles, Can the New York Stock Exchange Survive? INSTITUTIONAI INvEsToR, June 1970, at 25, 75-76. The possibilities for data manipulation increased when the Exchange departed from a cost-based rate struclure in its June 1970 proposal.

172. See pp. 834-35 supra.

173. See, e.g., Note, The Back Office and the Antitrust Laws, 69 CoL. L. REv. 299 (1969); Securities Investor Protection Hearings on H.R. 13308, H.R. 17585, H.R. IE0s1, H.R. 18109 and H.R. 18458 Before the Subcommittee on Commerce and Finance, 9lst Cong., 2d Sess. (1970).

174. An argument which has slowly been gaining support orer the past five jears, that automation is making the Big Board obsolete, is best summed up in the title of the article, Welles, Can the New York Stock Exchange Survive? Instrrumowal Investon, June 1970 , at 25 . Surveying the increasing disenchantment of institutional investors with the Exchange and the vast new possibilities for automation of the entire exchange mechanism, Welles asks of the Exchange, "do we need it?" Supra at 26. An automated system, which could supplant the New York Exchange as the central market place for all securities, has been set up by the National Association of Securities Dealers within the past jear. See Morgello, One Big Push-Button Market for All? NewsweEk, Nov. 30, 1970, at 74-75. Such a centralized system, which would take over all securities trading, is being seriously considered by William McChesney Martin, who was commissioned by the New York Stod: Exchange to survey its operations. Wall St. Journal, April 30, 1971, at 1, cl. 6. 
resolution of legislative conflicts by an administrative agency. Much antitrust policy is grounded in a mistrust of private interests combining to restrain trade. The informal bargaining pattern, because of its lack of openness to public scrutiny, presents some of the same dangers of substantial, unchecked power as do private combinations. Should the SEC adopt the procedural recommendations suggested here, the regulatory pattern would be better adapted for fairly making decisions in this area; but even with such formalities, Congress needs to face directly the question of whether the SEG is an appropriate institution for making such decisions.

Justice Douglas' shotgun-behind-the-door, rusty from disuse in the 1950 's was brought out by an aggressive SEC during much of the 1960's. It proved a powerful weapon when wielded by sure-shot SEC officials, but it also demonstrated serious short-comings when used in an informal bargaining pattern where great discretion prevailed. Having been pulled from behind the door, the shotgun now needs oiling through formalization of Commission procedures and Congressional examination of the targets at which it should be aimed. Formalization is the best weapon for continuing to pursue the goals of the Securities and Exchange Act of 1934 as the nation's securities markets face the problems of the 1970 's. 